Utah State University

DigitalCommons@USU

\title{
Ten-year results from the long-term soil productivity study in aspen ecosystems of the northern Great Lakes region
}

Richard Voldseth

Brian Palik

John Elioff

Follow this and additional works at: https://digitalcommons.usu.edu/aspen_bib

Part of the Forest Sciences Commons

\section{Recommended Citation}

Voldseth, R.; Palik, B.; Elioff, J. 2011. Ten-year results from the long-term soil productivity study in aspen ecosystems of the northern Great Lakes region. USDA-FS Northern Research Station, Research Paper NRS-17

This Document is brought to you for free and open access by the Aspen Research at DigitalCommons@USU. It has been accepted for inclusion in Aspen Bibliography by an authorized administrator of DigitalCommons@USU. For more information, please contact digitalcommons@usu.edu.

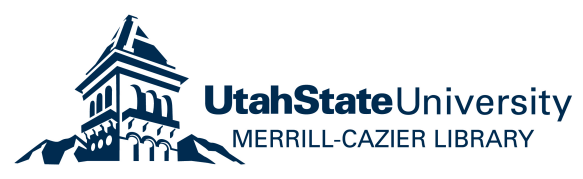




\section{USDA}

United States

Department of

Agriculture

Forest

Service

Northern

Research Station

Research Paper NRS-17

UAs
Ten-year Results from the

Long-term Soil Productivity Study in Aspen Ecosystems of the Northern Great Lakes Region

Richard Voldseth Brian Palik John Elioff

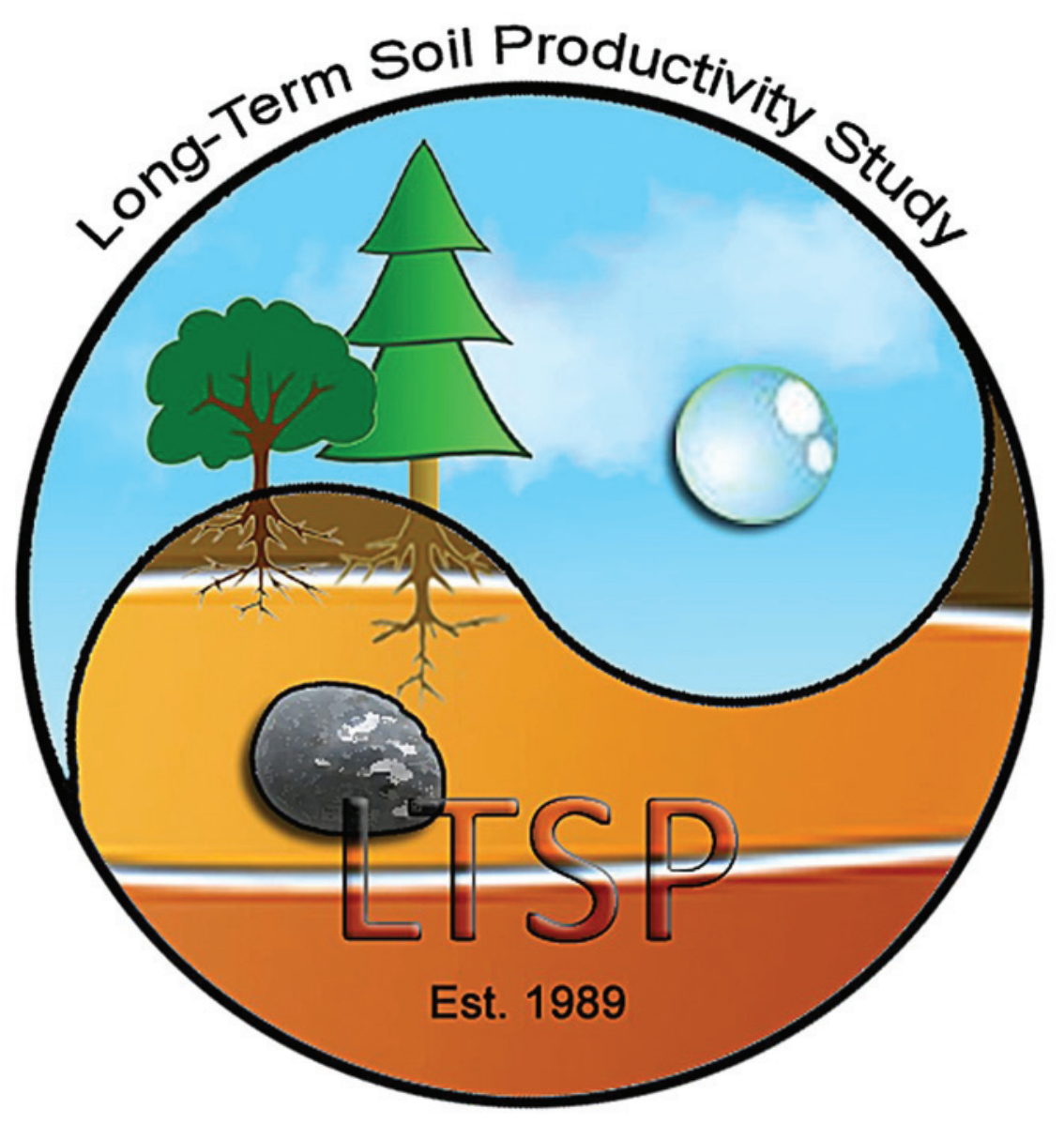




\section{Abstract}

Impacts of organic matter removal and compaction on soil physical and chemical properties and forest productivity are reported from the first 10 years of the Long-Term Soil Productivity Study in Great Lakes aspen ecosystems. Organic matter removal treatments included main bole, total tree harvest, and total tree harvest with forest floor removal. Compaction treatments included no compaction beyond normal levels from harvest, moderate compaction, and heavy compaction. Main bole harvest with no additional compaction served as the control against which other treatments were compared. Study treatments were replicated in three locations on a clay loam, silt loam, and loamy sand soil. All compaction treatments on all three soil types increased bulk density above preharvest levels. In most cases, bulk density at year 10 had decreased significantly compared to year 0 , but was still generally above preharvest levels. Total carbon and nitrogen showed no impact from treatment at year 10. In general, soil cations were little affected by organic matter removal. The major exceptions were lower near-surface calcium in the loamy sand soil with total tree harvest plus forest floor removal, and lower potassium at 10-20 cm depth in the loam soil for both total tree harvest with and without forest floor removal. Compaction and organic matter removal treatments impacted aboveground forest productivity, however the effects were not universal across the soil types. Aboveground biomass production declined on the loam soil with moderate and heavy compaction. Production increased with moderate compaction on the loamy sand and clay loam soils, but significantly decreased with heavy compaction on the clay loam soil. Total tree harvest with forest floor removal reduced production on the loamy sand and loam soils, while it increased production on the clay loam soil. Results from this study suggest that heavy compaction and/or high organic matter removals (e.g., total tree harvest plus forest floor removal) are generally detrimental to sustaining forest productivity across soil types. Total tree harvest with limited compaction may be sustainable, at least as reflected in 10 year results, after one harvest entry. Managers should be cautious of approaches involving whole-tree harvests, or even bole-only harvests, on short rotations ( 10 years), as such approaches will limit the potential for recovery to preharvest bulk densities and may have the potential to increase compaction to levels seen with heavy compaction.

Manuscript received for publication January 2011

Published by:

USDA FOREST SERVICE

11 CAMPUS BLVD., SUITE 200

NEWTOWN SQUARE, PA 19073-3294

September 2011
For additional copies:

USDA Forest Service

Publications Distribution

359 Main Road

Delaware, $\mathrm{OH}$ 43015-8640

Fax: 740-368-0152

Visit our homepage at: http://www.nrs.fs.fed.us/ 


\section{INTRODUCTION}

In the face of increased interest in utilization of wood fiber for biofuels, sustaining long-term site productivity is a fundamental issue confronting forest management (Hendrickson et al. 1989, Powers et al. 1990a, Walmsley et al. 2009). Site productivity, that we here define as sustained capacity to capture carbon and produce plant biomass, is affected by environmental drivers, such as climate. Within the limits of climate, the potential net primary productivity of a site is regulated by biotic, chemical, and physical soil properties and processes, which, in turn, can be altered by human-caused disturbances (Powers et al. 2004). How soil disturbances affect productivity of forests is still not well understood (Powers et al. 2005).

Soil properties directly affected by disturbance include porosity and organic matter content (Powers et al. 1990b). Porosity and organic matter regulate fundamental ecosystem processes through their influence on water and gas exchange, physical restrictions on rooting, microbial activity, soil aggregate stability, and resource availability. Forest harvesting can reduce porosity through compaction by machinery traffic. Soil porosity reflects a continuum of void sizes that vary with the mineral nature and degree of weathering of the parent material (Powers 1999). The mechanism by which soil compaction impacts productivity is through the breakdown of surface aggregates causing decreased macropore volume and increased soil bulk density (Powers 1999, Pritchett and Fisher 1987). This can impede both root growth and water infiltration, and can alter the balance of oxygen and carbon dioxide in the soil profile and gas exchange with the atmosphere which, in turn, can alter soil pH and nutrient regimes (Ballard 2000, Powers 1999).

Soil organic matter content is directly related to the amount of organic matter entering the soil from plant tissue. Forest floor organic matter constitutes an energy source for soil fauna and microbes and is a reservoir of nutrients supplied to the soil through pulses in litterfall and root sloughage. Direct removal of plant and plant-derived organic matter, including the forest floor, as well as reduced capacity to produce new organic matter, can lead to reductions in soil organic matter concentrations. Moreover, the loss of forest floor can result in increased soil temperatures and a reduction of decomposition products that aid in the development of soil structural aggregates (Powers 1999). Soil organic matter loss can also lead to decreases in soil water-holding capacity and can alter soil ion exchange and nutrient capital (Powers 1999, Zabowski et al. 1994).

\section{The Authors}

RICHARD VOLDSETH is a research associate with the Department of Soil Science, North Dakota State University, Fargo, ND.

BRIAN PALIK is a research ecologist with the Center for Research on Ecosystem Change, Northern Research Station, Grand Rapids, MN.

JOHN ELIOFF is a forestry technician (retired) with the Center for Research on Ecosystem Change, Northern Research Station, Grand Rapids, MN. 
The North American Long-Term Soil Productivity (LTSP) Study was conceived to address the consequences of pulse soil disturbance on forest productivity, as impacted by reductions in soil porosity, through compaction, and soil organic matter content, through organic matter removal. The U.S. Department of Agriculture - Forest Service is legally bound by the National Forest Management Act of 1976 to manage land in such a way that its long-term productivity is not impaired (Powers et al. 1990a, Powers et al. 1990b, Powers 1999, Powers et al. 2005, Powers 2006, Tiarks et al. 1997). In response, the Forest Service has charged each region with the National Forest System (NFS) with developing soil quality monitoring standards that can detect losses in productive potential of the land over a rotation (PageDumroese et al. 2000, Powers et al. 1990a, Powers et al. 1990b). In 1989, as a result of these concerns and mandates, Forest Service research scientists and NFS managers set the foundation for the LTSP program (Powers 2006, Tiarks et al. 1997). Today, the LTSP program is an international endeavor with identical experimental designs and study questions being addressed at multiple sites.

The LTSP experiment specifically targeted soil porosity and organic matter for manipulation in large-scale, long-term experiments. The LTSP experiment was designed to address the following primary question: do pulse reductions in site organic matter and/or soil porosity reduce the sustained productive potential of a site? Treatments include three levels of soil compaction factored with three levels of aboveground organic matter removal. The ranges of treatments were chosen to encompass the range of possibilities occurring under contemporary management.

The Lake States installations of the LTSP Study are located in forests dominated by trembling and bigtooth aspen (Populus tremuloides Michx., Populus grandidentata Michx.). These forests are the dominant early successional forest type in the region (Schulte et al. 2007) and as such are of tremendous economic and ecological importance. Trembling aspen dominated forests are early successional across a range of site and soil conditions and develop with relatively uniform tree sizes with culmination of mean annual increment occurring around 30 to 40 years of age. They lend themselves to intense mechanized harvesting regimes and whole (total) tree utilization (Alban 1991) for wood products and, more recently, feedstocks for wood-based biofuels. The long-term productivity impacts of intensive harvesting and biomass removal for energy feedstocks are not well understood (Grigal 2000).

Monitoring of the LTSP Study is to be conducted over one full rotation or about 50 years. This report presents findings from the first 10 years of monitoring in the Lake States LTSP installations. Several tenth-year syntheses from the national effort have been published previously (Powers et al. 2004, 2005). Mirroring the national program, our primary objective for this project is to understand how organic matter removal and changes in soil porosity due to compaction affect a site's productive carrying capacity and, ultimately, sustainability of biomass production in aspen ecosystems. We asked the following questions: Is there an effect of organic matter removal or soil compaction on soil physical and chemical variables that may account for productivity responses? Is there an effect of organic matter removal or compaction treatments on vegetation productivity and abundance after 10 years? At what level of organic matter removal or compaction are effects evident?

\section{METHODS}

\section{Study Areas}

This study is based in three geographically separate locations, with each site representing a distinctly different soil texture. All sites were established in fully stocked evenaged stands of the aspen (Populus tremuloides Michx. and Populus grandidentata Michx.) (Stone 2001). The three sites were established in consecutive years for ease in establishment and field sampling logistics.

The first site, established in 1992, is on a clay loam soil located on the Ottawa National Forest in the upper peninsula of Michigan, USA (Fig. 1). Soils at this location were classified as Frigid Vertic Glossudalfs formed in lacustrine clays. This site occurs in the boreal moist Holdridge life zone (Lugo et al. 1999), 


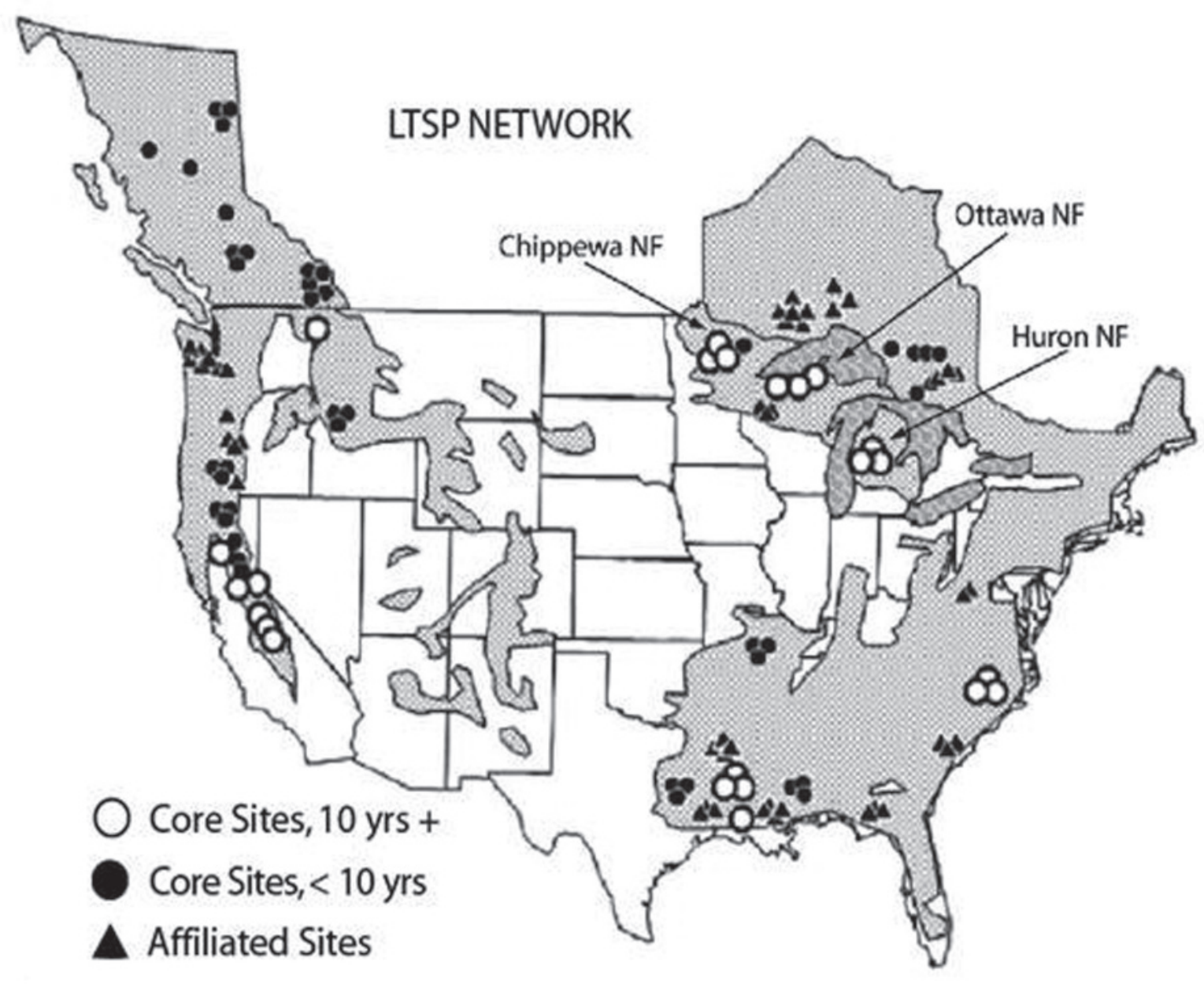

Figure 1.-LTSP core and affiliate sites relative to the approximate range of commercial forest in the United States and portions of Canada (after Powers et al. 2005). Open circles indicate sites that had at least 10 years of data by 2005. The approximate locations of the Chippewa, Ottawa, and Huron National Forest LTSP sites are indicated.

at an approximate elevation of 350 m.a.s.1. Mean annual precipitation is about $77 \mathrm{~cm}$. Stand age at time of establishment was 60 years, with a site index for aspen at age 50 years estimated at $17 \mathrm{~m}$ (Stone 2001). Trees were harvested in late January and early February 1992. Snow depth averaged approximately $80 \mathrm{~cm}$ over unfrozen soils (Stone 2001).

The second site, established in 1993, is on a silt loam soil located on the Chippewa National Forest in northern Minnesota, USA (Fig. 1). Soils were classified as Frigid Haplic Glossudalfs formed in loess and till. This site occurs in the boreal moist Holdridge life zone at an approximate elevation of 410 m.a.s.1. Mean annual precipitation is about $64 \mathrm{~cm}$. Stand age at time of study establishment was 70 years, with a site index for aspen at age 50 years estimated at $23 \mathrm{~m}$ (Stone 2001). Trees were harvested in January and February 1993. Average snow depth increased over the period of harvest from approximately $30 \mathrm{~cm}$ to $46 \mathrm{~cm}$ over discontinuously frozen soils; frost ranged in depth from 5 to $10 \mathrm{~cm}$ by end of harvest (Stone 2001). 
The third site, established in 1994, is on a loamy sand soil on the Huron National Forest in eastern Michigan, USA (Fig. 1). Soils were classified as Frigid Typic Udipsamments and Frigid Entic Haplorthods formed in outwash sands. This site occurs in the cool temperate moist Holdridge life zone at an approximate elevation of 240 m.a.s.l. Mean annual precipitation is about $75 \mathrm{~cm}$. Stand age at time of establishment was 35 years, with a site index for aspen at age 50 years estimated at $19 \mathrm{~m}$ (Stone 2001). Trees were harvested in late January 1994. Average snow depth was approximately $37 \mathrm{~cm}$ over frozen soils; depth of frost averaged nearly $22 \mathrm{~cm}$ (Stone 2001).

\section{Experimental Design}

This research is based on a conceptual model (Fig. 2) developed by the National LTSP Program (Powers et al. 1990b, Powers et al. 2005) and applied to the northern Great Lakes aspen ecosystem study.

The experimental design includes three factors (compaction, organic matter removal, year), with treatments arranged in a randomized complete block (replicates). There were three levels of soil compaction (C) and three levels of organic matter removal (OM), for a total of nine core treatments (Table 1). The levels of compaction were: $\mathrm{C}_{0}$, no additional compaction above that due to harvesting; $\mathrm{C}_{1}$, moderate compaction; and $\mathrm{C}_{2}$, heavy compaction. The levels of organic matter removal were: $\mathrm{OM}_{0}$, main bole only harvest; $\mathrm{OM}_{1}$, aboveground total tree harvest; and $\mathrm{OM}_{2}$, aboveground total tree harvest plus removal of forest floor.

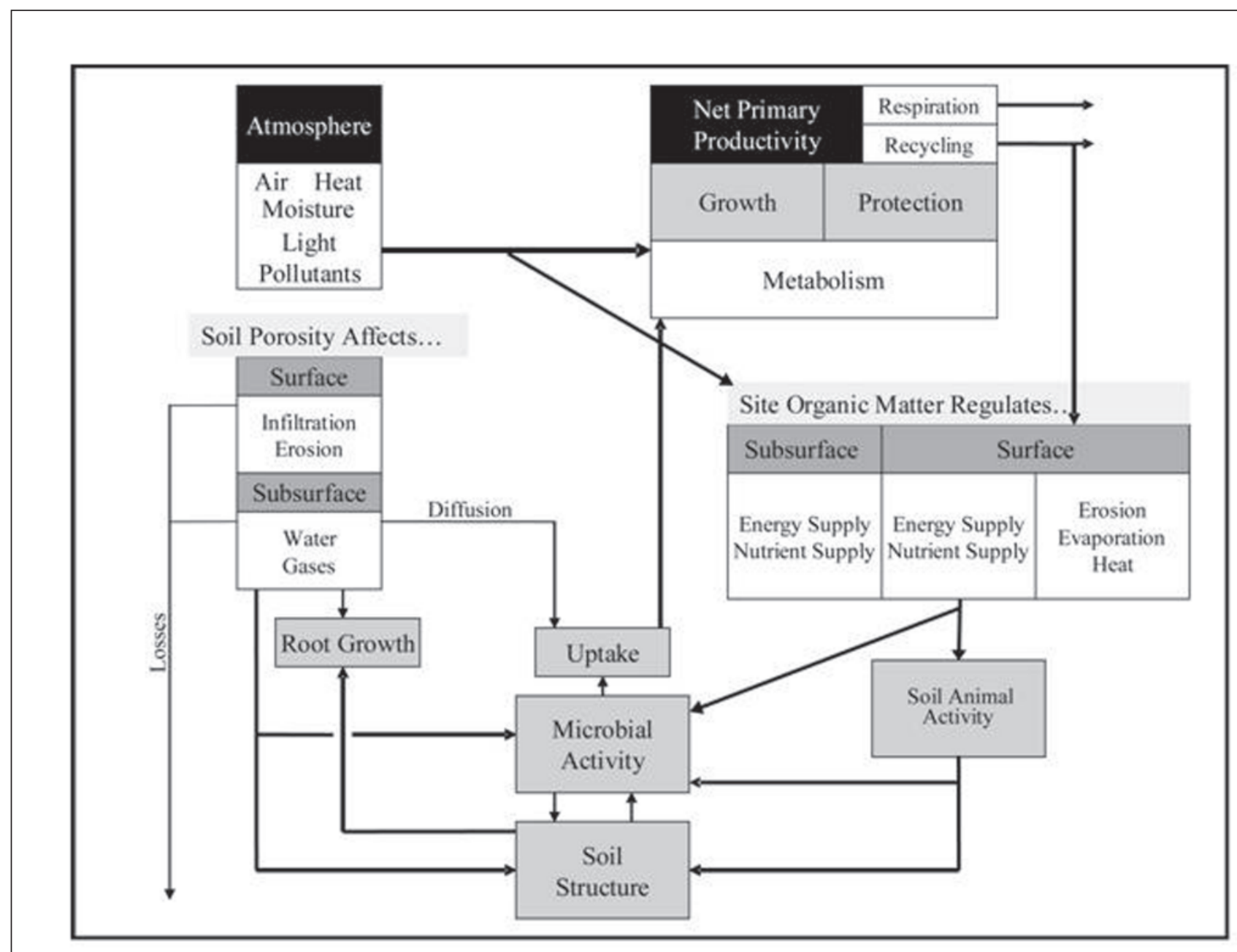

Figure 2.-Conceptual model used to guide the LTSP experimental design, indicating the overriding influence of soil porosity and site organic matter on fundamental processes that regulate primary productivity within climatic constraints (after Powers et al. 1998, Powers et al. 2005). 
Table 1.-Description of compaction and organic matter removal treatments.

\begin{tabular}{cccc}
\hline \multirow{2}{*}{ Compaction } & & Organic Matter Removal & \\
\cline { 2 - 4 } & $\mathrm{OM}_{0}$ & $\mathrm{OM}_{1}$ & $\mathrm{OM}_{2}$ \\
\hline $\mathrm{C}_{0}$ & $\begin{array}{c}\text { Main bole harvest, } \\
\text { no additional compaction } \\
\left(\mathrm{C}_{0}, \mathrm{OM}_{0}\right)\end{array}$ & $\begin{array}{c}\text { Total tree harvest, } \\
\text { nodditional compaction } \\
\left(\mathrm{C}_{0}, \mathrm{OM}_{1}\right)\end{array}$ & $\begin{array}{c}\text { Total tree harvest + forest } \\
\text { floor removal, no additional } \\
\text { compaction }\left(\mathrm{C}_{0}, \mathrm{OM}_{2}\right)\end{array}$ \\
\hline \multirow{2}{*}{$\mathrm{C}_{1}$} & $\begin{array}{c}\text { Main bole harvest, } \\
\text { moderate compaction } \\
\left(\mathrm{C}_{1}, \mathrm{OM}_{0}\right)\end{array}$ & $\begin{array}{c}\text { Total tree harvest, } \\
\text { moderate compaction } \\
\left(\mathrm{C}_{1}, \mathrm{OM}_{1}\right)\end{array}$ & $\begin{array}{c}\text { Total tree harvest + forest floor } \\
\text { removal, moderate compaction } \\
\left(\mathrm{C}_{1}, \mathrm{OM}_{2}\right)\end{array}$ \\
\hline $\mathrm{C}_{2}$ & $\begin{array}{c}\text { Main bole harvest, } \\
\text { heavy compaction } \\
\left(\mathrm{C}_{2}, \mathrm{OM}_{0}\right)\end{array}$ & $\begin{array}{c}\text { Total tree harvest, } \\
\text { heavy compaction } \\
\left(\mathrm{C}_{2}, \mathrm{OM}_{1}\right)\end{array}$ & $\begin{array}{r}\text { Total tree harvest } \\
+ \text { forest floor removal, }\end{array}$ \\
& & & heavy compaction $\left(\mathrm{C}_{2}, \mathrm{OM}_{2}\right)$ \\
\hline
\end{tabular}

Each set of nine treatments was replicated three times at each geographic location on $50 \mathrm{~m} \times 50 \mathrm{~m}$ treatment plot. Plots were established prior to logging and treatments were randomly assigned to the plots. After harvesting, the forest floor on the $\mathrm{OM}_{2}$ treatment was removed by hand raking down to the top of the mineral soil and removing the material from the site prior to applying compaction treatments. Compaction treatments were applied during early spring with one or more passes using a Caterpillar tractor or frontend loader. Additional detail on the study areas and the equipment used to apply treatments can be found in Stone (2001). After treatment installation, all plots regenerated naturally to aspen and associated species, with the exception of the Chippewa National Forest site. At this site, some new aspen suckers were damaged from late application of compaction treatments; in these plots, additional aspen seedlings were planted to offset any potential losses in initial low stocking.

\section{Field Measurements}

Soil was collected and vegetation measurements were made prior to harvest, prior to compaction treatment (post-organic matter removal), post-compaction (i.e. post-treatment at end of the same growing season in which compaction was applied or year 0 ), in year 1 , year 5 , and year 10 . Year 5 results are not presented in this report as earlier results have been reported elsewhere (Stone 2001, 2002). All sampling and measurements were conducted within the interior $40 \mathrm{~m}$ x $40 \mathrm{~m}$ of each plot, allowing a 5-m buffer around the target sample area. Initially, five sample points were established systematically and uniformly within each treatment plot. In year 5, the number of points was expanded to eight, and in year 10 to nine points.

\section{Soil}

In each measurement year, a random azimuth and a distance (range of 1 to $3 \mathrm{~m}$ ) from a sample point center was determined and used to locate a sampling area for soil. New sampling locations were constrained to be at least $1 \mathrm{~m}$ from the previous sample location. Soil samples were collected using a $30 \mathrm{~cm}$ deep by $6.35 \mathrm{~cm}$ diameter $\left(190.5 \mathrm{~cm}^{3}\right)$ stainless steel core fitted with a plastic tube. Tubes were removed and taken to the lab for processing.

\section{Vegetation}

In each treatment plot, aboveground herbaceous vegetation was collected at five sample points in $1-\mathrm{m}^{2}$ clip plots during late July to early August. Clip plot locations were determined similar to soil samples points, as described above. Woody shrub and tree vegetation was sampled in mid-September to October in $10-\mathrm{m}^{2}$ subplots centered on the sample points. All woody stems $>15 \mathrm{~cm}$ tall were measured and recorded by $2-\mathrm{mm}$ diameter classes, with diameters measured at stem heights of $25 \mathrm{~cm}$ for individuals $<1.4 \mathrm{~m}$ tall and at $1.4 \mathrm{~m}$ for individuals reaching this height. 


\section{Sample Preparation and Data Summarization}

Plant material from the clip plots was oven dried at $60{ }^{\circ} \mathrm{C}$ for 48 hours, and weighed to determine dry weight biomass. Allometric equations developed for this study (Perala and Alban 1993) were used to estimate aboveground biomass $\left(\mathrm{Mg} \mathrm{ha}^{-1}\right)$ of all woody species. Stem counts were used to determine densities of woody species (number ha-1). Estimates of biomass and densities were determined for aspen alone, as well as the total for all woody vegetation combined.

Soil cores were sectioned into $0-10 \mathrm{~cm}, 10-20 \mathrm{~cm}$ and 20-30 cm depth segments. Mineral soil samples from these sections were sieved to the 2-mm fraction to remove coarse fragments and root material. Samples were then oven-dried at $105{ }^{\circ} \mathrm{C}$ until no further loss of moisture could be detected after several repeated weighings. The following soil measures were determined from these samples: soil bulk density $(\mathrm{Db}$, $\left.\mathrm{g} \mathrm{cm}^{-3}\right)$; total soil carbon storage $\left(\mathrm{Mg} \mathrm{ha}^{-1}\right)$; total soil nitrogen storage $\left(\mathrm{Mg} \mathrm{ha}^{-1}\right)$; calcium $\left(\mathrm{Ca}, \mathrm{cmol} \mathrm{kg}^{-1}\right)$; potasium ( $\left.\mathrm{K}, \mathrm{cmol} \mathrm{kg}^{-1}\right)$; magnesium $\left(\mathrm{Mg}, \mathrm{cmol} \mathrm{kg}^{-1}\right)$; sodium ( $\left.\mathrm{Na}, \mathrm{cmol} \mathrm{kg}^{-1}\right)$; and effective cation exchange capacity (CECe, $\mathrm{cmol} \mathrm{kg}^{-1}$ ).

Fine fraction $\mathrm{Db}$ was determined as the mass of the $<2 \mathrm{~mm}$ diameter material, from each depth category, divided by the volume occupied by that material. Soil samples used in the $\mathrm{Db}$ determinations were combined within a treatment plot by depth category, thoroughly mixed, and subsampled for chemical analysis. Total $\mathrm{C}$ and $\mathrm{N}$ determinations were made on a Carlo Erba Model NA 1500 series 2 nitrogen/carbon/sulphur analyzer (CE Elantech, Inc., Lakewood, NJ). Cations were extracted using Mehlich 3 solution with detection by inductively coupled plasma analysis (Wolf and Beegle 1995). Total CECe was determined by summing $\mathrm{Ca}, \mathrm{Mg}, \mathrm{K}$, and $\mathrm{Na}$ (Ross 1995).

\section{Statistical Analysis}

Each location in the study was analyzed separately due to large differences in climate and soil type. At each location, subplot data were averaged to derive treatment plot means for $\mathrm{n}=$ three replicates for treatment combinations, with the following exceptions: an error at the time of treatment installation at the Ottawa site resulted in only one replicate for the heavy compaction + main bole harvest treatment $\left(\mathrm{C}_{2} \mathrm{OM}_{0}\right)$, two replicates for the moderate compaction + main bole harvest treatment $\left(\mathrm{C}_{1} \mathrm{OM}_{0}\right)$, and five replicates for the moderate compaction + total aboveground organic matter removal treatment $\left(\mathrm{C}_{1} \mathrm{OM}_{2}\right)$. For the Ottawa analyses, the mixed procedure in SAS (see below) was used to account for the unbalanced design (Littell et al. 1996).

All response variables were found to meet or nearly meet assumptions of normality. Covariance structures available within SAS were evaluated for each data set, with an autoregressive model determined as best fit (smallest variance) for this mixed-model approach. The autoregressive structure has homogeneous variances and correlations that decline exponentially with time.

Repeated measures analyses were conducted on each response variable using the "proc mixed" procedure in SAS (SAS Institute Inc. 1999) with replications considered as random effects. The mixed effects model used was:

$$
\begin{gathered}
\mathrm{Y}_{\mathrm{jklm}}=\mu_{\mathrm{Y}}+\alpha_{\mathrm{j}}+\beta_{\mathrm{k}}+\gamma_{1}+\rho_{\mathrm{m}}+(\alpha \beta)_{\mathrm{jk}}+(\alpha \gamma)_{\mathrm{jl}} \\
+(\alpha \rho)_{\mathrm{jm}}+(\beta \gamma)_{\mathrm{kl}}+(\beta \rho)_{\mathrm{km}}+(\gamma \rho)_{\mathrm{lm}}+(\alpha \beta \gamma)_{\mathrm{jkl}} \\
+(\alpha \beta \rho)_{\mathrm{jkm}}+(\alpha \gamma \rho)_{\mathrm{jlm}}+(\beta \gamma \rho)_{\mathrm{klm}}+\mathrm{C}_{\mathrm{jklm}}
\end{gathered}
$$

where

$\mathrm{Y}_{\mathrm{jklm}}$ is the measured response for the $\mathrm{m}^{\text {th }}$ replication of the $1^{\text {th }}$ year for the $\mathrm{k}^{\text {th }}$ organic matter removal treatment and the $\mathrm{j}^{\text {th }}$ compaction treatment,

$\mu_{\mathrm{Y}}$ is the overall mean of $\mathrm{Y}_{\mathrm{jklm}}$,

$\alpha_{j}$ is the fixed effect due to $j^{\text {th }}$ compaction treatment,

$\beta_{\mathrm{k}}$ is the fixed effect due to $\mathrm{k}^{\text {th }}$ organic matter removal treatment,

$\gamma_{1}$ is the fixed effect due to $1^{\text {th }}$ year,

$\rho_{\mathrm{m}}$ is the random effect or block due to the $\mathrm{m}^{\text {th }}$ replication,

$(\alpha \beta)_{\mathrm{jk}}$ is the interaction fixed effect due to the $\mathrm{k}^{\text {th }}$ organic matter removal treatment and the $\mathrm{j}^{\text {th }}$ compaction treatment, 
$(\alpha \gamma)_{\mathrm{j} 1}$ is the interaction fixed effect due to the $1^{\text {th }}$ year for the $\mathrm{j}^{\text {th }}$ compaction treatment,

$(\alpha \rho)_{\mathrm{jm}}$ is the random effect due to the $\mathrm{m}^{\text {th }}$ replication for the $\mathrm{j}^{\text {th }}$ compaction treatment,

$(\beta \gamma)_{\mathrm{kl}}$ is the interaction fixed effect due to the $\mathrm{t}^{\text {th }}$ year for the $\mathrm{k}^{\text {th }}$ organic matter removal treatment,

$(\beta \rho)_{\mathrm{km}}$ is the random effect due to the $\mathrm{m}^{\text {th }}$ replication for the $\mathrm{k}^{\text {th }}$ organic matter removal treatment,

$(\gamma \rho)_{\operatorname{lm}}$ is the random effect due to the $\mathrm{m}^{\text {th }}$ replication for the $1^{\text {th }}$ year,

$(\alpha \beta \gamma)_{\mathrm{jkl}}$ is the interaction fixed effect due to the $1^{\text {th }}$ year for the $\mathrm{k}^{\text {th }}$ organic matter removal treatment and the $\mathrm{j}^{\text {th }}$ compaction treatment,

$(\alpha \beta \rho)_{\mathrm{jkm}}$ is the random effect due to the $\mathrm{m}^{\text {th }}$ replication for the $\mathrm{k}^{\text {th }}$ organic matter removal treatment and the $\mathrm{j}^{\text {th }}$ compaction treatment,

$(\alpha \gamma \rho)_{\mathrm{jlm}}$ is the random effect due to the $\mathrm{m}^{\text {th }}$ replication of the $1^{\text {th }}$ year for the $\mathrm{j}^{\text {th }}$ compaction treatment,

$(\beta \gamma \rho)_{\mathrm{klm}}$ is the random effect due to the $\mathrm{m}^{\text {th }}$ replication of the $1^{\text {th }}$ year for the $\mathrm{k}^{\text {th }}$ organic matter removal treatment,

$\epsilon_{j k l m}$ is the random error due to the $\mathrm{m}^{\text {th }}$ replication of the $1^{\text {th }}$ year for the $\mathrm{k}^{\text {th }}$ organic matter removal treatment and the $\mathrm{j}^{\text {th }}$ compaction treatment.

Five-year intervals were used for analyses. The Satterthwaite degrees of freedom approximation was utilized in SAS, which can produce non-integer denominator degrees of freedom (Littell et al. 1996).

Comparisons were conducted via least squares means (LSM) to test for rejection of the null hypotheses that no differences existed among treatment means. The differences of LSM were computed in SAS using the "pdiff" option. In the case of the unbalanced design at the Ottawa site, the results of the LSM may not equal the average of the data because LSM imposes the model structure on the calculated mean and these adjusted means guarantee an unbiased estimation of treatment means (Littell et al. 1996, Spilke 2005).

Twenty-four response variables were evaluated for each site, including bulk density ( $\mathrm{Db}$ ), total carbon, and total nitrogen at three soil depths, $\mathrm{CECe}, \mathrm{Ca}, \mathrm{K}$,
$\mathrm{Mg}, \mathrm{Na}$ at two soil depths, aboveground total plant biomass, aspen biomass, herbaceous biomass, total woody species stem density and aspen stem density. Statistical tests were considered significant at $\mathrm{p} \leq 0.05$.

Our analyses produced a large number of comparisons among treatments and over time, however the focus of this report is primarily on tenth year responses, with some comparisons to year 0 values for selected variables. By design, the no additional compaction + main bole harvest treatment $\left(\mathrm{C}_{0} \mathrm{OM}_{0}\right)$ served as the control for testing the effects of all other treatments in this experiment (Powers 1999). Additionally, some comparisons were made with preharvest data.

\section{RESULTS}

\section{Interactions between Compaction and Organic Matter Removal}

Very few statistically significant interactions between soil compaction and organic matter removal were detected for most variables within the first decade since treatment. Of 75 possible two-way interactions we examined, only seven were significant at $p \leq 0.05$. This indicates that for the most part, responses to increasing compaction or increasing removal of organic matter were independent of the level of the other variable. The majority of significant interactions were at the Chippewa National Forest silt loam soil site: CECe at $0-10 \mathrm{~cm}, \mathrm{Ca}$ at $0-10 \mathrm{~cm}$, along with total biomass, aspen biomass, and total stem density. Also, interactions for total stem density and $\mathrm{Na}$ at $10-20 \mathrm{~cm}$ at Ottawa National Forest clay loam soil site were significant. Due to the minimal number of statistically significant interactions, hereafter we test for differences among levels of one main effect (e.g., soil compaction) at the control level of the second main effect (e.g., organic matter removal).

\section{Soil Bulk Density}

\section{Loamy Sand Soil}

Immediately after treatment, both moderate $\left(\mathrm{C}_{1}\right)$ and heavy $\left(\mathrm{C}_{2}\right)$ compaction, pooled across organic matter removal treatments, on the loamy sand soil, resulted in significant $(\mathrm{p}<0.05)$ increases in bulk density compared to $\mathrm{C}_{0}$ (no additional compaction) except that 
no significant difference was detected between $\mathrm{C}_{0}$ and $\mathrm{C}_{1}$ at 20-30 cm (Fig. 3). Moreover, bulk density on all treatments at all depths was elevated above the mean preharvest values (Fig. 3). For comparison, when compaction treatments were compared within just $\mathrm{OM}_{0}$ (main bole only treatment), bulk density for both $\mathrm{C}_{1}$ and $\mathrm{C}_{2}$ were still significantly greater than $\mathrm{C}_{0}$ at all depths, although $\mathrm{C}_{1}$ and $\mathrm{C}_{2}$ did not differ significantly from each other (data not shown). For all compaction treatments, bulk density at $0-10 \mathrm{~cm}$ had significantly decreased by year 10 , compared to year 0 , and bulk density for $\mathrm{C}_{1}$ and $\mathrm{C}_{2}$ were no longer significantly higher than $\mathrm{C}_{0}$ (Fig. 4). At the two deeper depths, bulk density values at year 10 remained significantly greater $(\mathrm{p}<0.05)$ than the control $\left(\mathrm{C}_{0}\right)$ for moderate compaction $\left(\mathrm{C}_{1}\right)$ at $10-20 \mathrm{~cm}$, and heavy compaction $\left(\mathrm{C}_{2}\right)$ at $10-20$ and $20-30 \mathrm{~cm}$. Also, at year 10, bulk density of all treatments at all depths remained higher than the mean preharvest values.

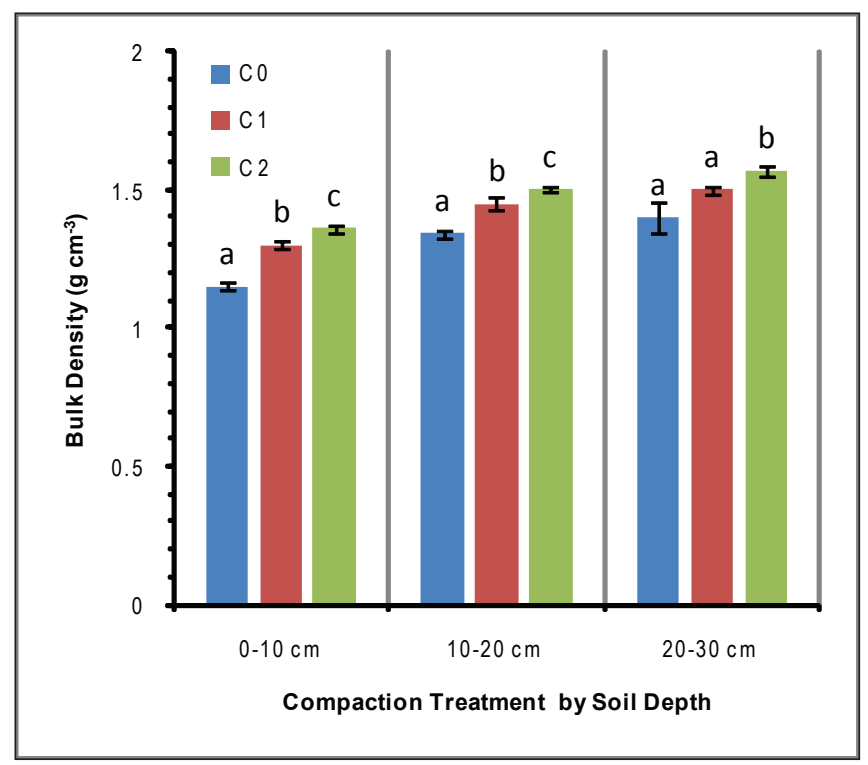

Figure 3.-Means and standard errors for bulk density immediately following application (year 0 ) of $\mathrm{C}_{1}$ (medium) and $\mathrm{C}_{2}$ (heavy) compaction treatments, relative to $\mathrm{C}_{0}$ (no additional compaction), for three soil depths on loamy sand soil at the Huron National Forest. Mean values for each compaction treatment are pooled across all organic matter removal treatments. Bars with common letters indicate means were not significantly different $(p \leq 0.05)$. Significance tests of compaction treatments apply within each soil depth category only. Dashed horizontal lines are mean preharvest bulk density values, pooled across all treatments by depth.

\section{Silt Loam Soil}

Immediately after treatment, both moderate $\left(\mathrm{C}_{1}\right)$ and heavy $\left(\mathrm{C}_{2}\right)$ compaction treatments, pooled across all organic matter removal treatments, resulted in significantly greater $(\mathrm{p}<0.05)$ bulk density compared to $\mathrm{C}_{0}$, but only at $0-10 \mathrm{~cm}$ (Fig. 5). However, bulk densities on all treatments at all depths were elevated above the mean preharvest values (Fig. 5). For comparison, when compaction treatments were compared within just $\mathrm{OM}_{0}$, bulk density for both $\mathrm{C}_{1}$ and $\mathrm{C}_{2}$ were no longer significantly different from $\mathrm{C}_{0}$ at the $0-10 \mathrm{~cm}$ soil depth (data not shown). Only heavy compaction $\left(\mathrm{C}_{2}\right)$ at $0-10 \mathrm{~cm}$ had a significant decrease in bulk density by year 10, compared to year 0 (Fig. 6). At the two deeper depths, there were no treatment differences $(p>0.05)$ in bulk density at year 10 . However, at year 10, bulk density of all treatments at all depths remained substantially higher than the mean preharvest values.

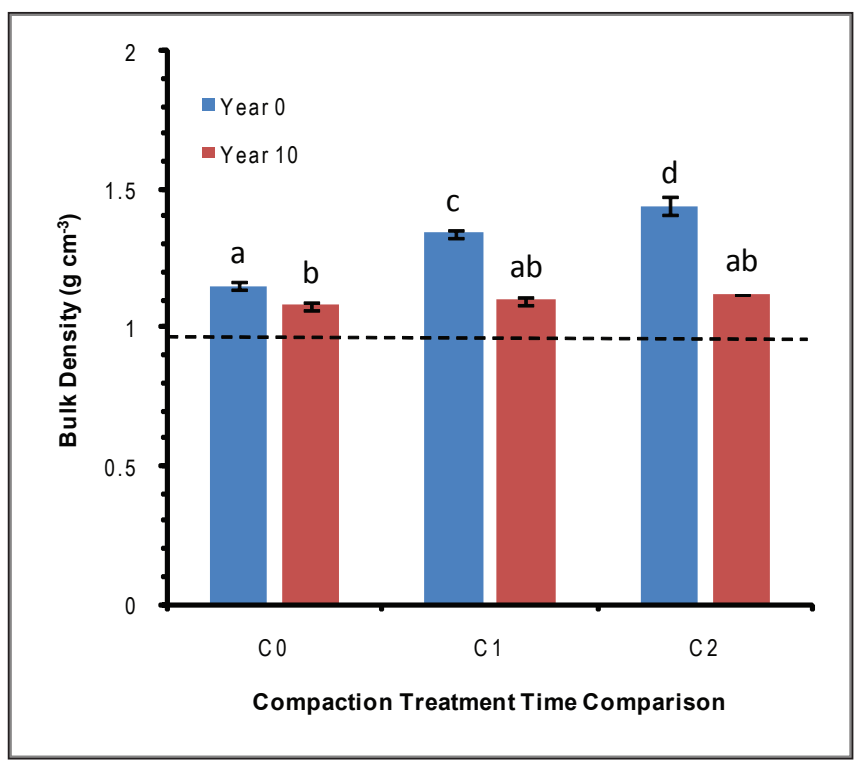

Figure 4.-Means and standard errors for bulk density of compaction treatments at $0-10 \mathrm{~cm}$ immediately after treatment ( $\mathrm{yr} 0$ ) and 10 years after treatment ( $\mathrm{yr} 10)$ for the loamy sand soil at the Huron National Forest. Bars with common letters indicate means are not significantly different $(p \leq 0.05)$. Dashed horizontal line is the mean preharvest bulk density pooled across all treatment. Compaction treatments are constrained to $\mathrm{OM}_{0}$. 


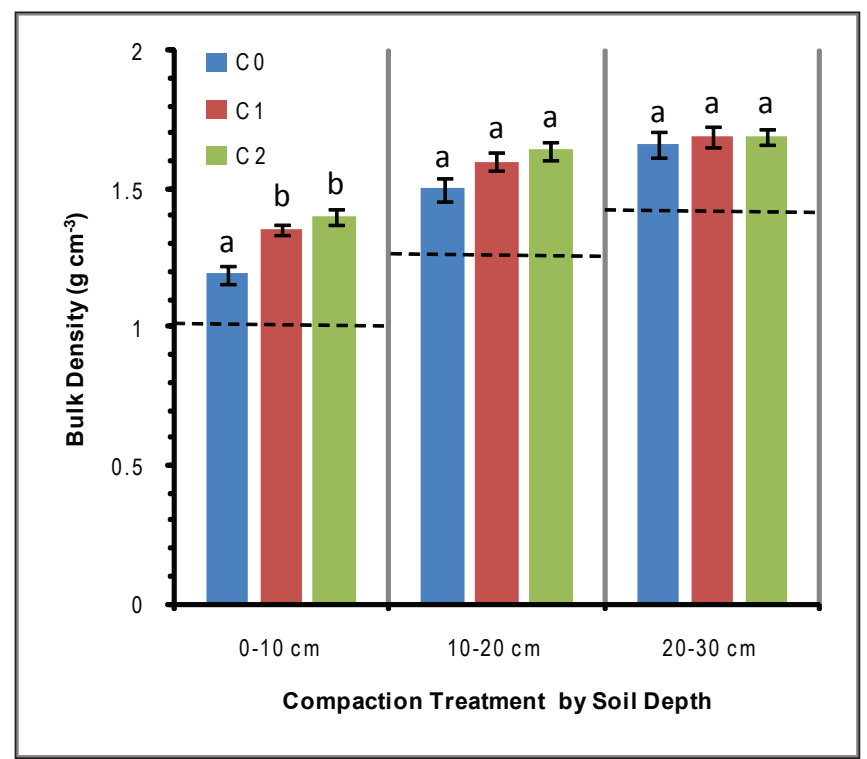

Figure 5.-Means and standard errors for bulk density immediately following application (year 0 ) of $\mathrm{C}_{1}$ (medium) and $C_{2}$ (heavy) compaction treatments, relative to $C_{0}$ (no additional compaction), for three soil depths on silt loam soil at the Chippewa National Forest. Mean values for each compaction treatment are pooled across all organic matter removal treatments. Bars with common letters indicate means were not significantly different $(p \leq 0.05)$. Significance tests of compaction treatments apply within each soil depth category only. Dashed horizontal lines are mean preharvest bulk density values, pooled across all treatments by depth.

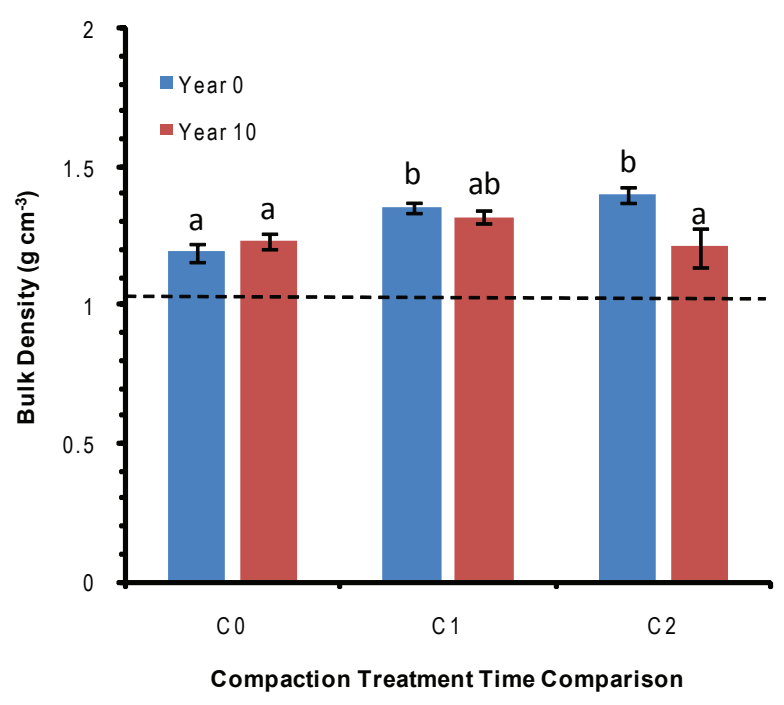

Figure 6.-Means and standard errors for bulk density of compaction treatments at $0-10 \mathrm{~cm}$ immediately after treatment (yr 0) and 10 years after treatment (yr 10) for silt loam soil at the Chippewa National Forest. Bars with common letters indicate means are not significantly different $(p \leq 0.05)$. Dashed horizontal line is the mean preharvest bulk density pooled across all treatment. Compaction treatments are constrained to $\mathrm{OM}_{0}$.

\section{Clay Loam Soil}

Immediately after treatment, both moderate $\left(\mathrm{C}_{1}\right)$ and heavy $\left(\mathrm{C}_{2}\right)$ compaction treatments, pooled across all organic matter removal treatments, on the clay loam soil, resulted in significantly greater $(\mathrm{p}<0.05)$ bulk density compared to $\mathrm{C}_{0}$, at all depths, except that $\mathrm{C}_{1}$ and $\mathrm{C}_{0}$ did not differ at 20-30 cm (Fig. 7). Bulk density of all treatments was substantially elevated above the mean preharvest value only at $0-10 \mathrm{~cm}$ (Fig. 7). Bulk density was moderately elevated above the preharvest value at $10-20 \mathrm{~cm}$ and similar to the preharvest value at 20-30 cm (Fig. 7). For comparison, when compaction treatments were compared within just OM0, bulk densities were significantly different for most comparisons with $\mathrm{C}_{0}$, except $\mathrm{C}_{1}$ at $0-10 \mathrm{~cm}$ and $\mathrm{C}_{2}$ at 20-30 cm (data not shown). For all treatments, bulk density in year 10 was not significantly different than year 0 at $0-10 \mathrm{~cm}$, but bulk density was significantly greater for $\mathrm{C}_{2}$ compared to both $\mathrm{C}_{0}$ and $\mathrm{C}_{1}$ at year 10 (Fig. 8). At the two deeper depths in year 10 , bulk density was not significantly different than the control $\left(\mathrm{C}_{0}\right)$ for either medium $\left(\mathrm{C}_{1}\right)$ or heavy compaction $\left(\mathrm{C}_{2}\right)$ (data not shown). At year 10, bulk density of all treatments at $0-10 \mathrm{~cm}$ remained higher than the mean preharvest values (Fig. 8), whereas bulk density at deeper depths was very similar to preharvest values (data not shown). 


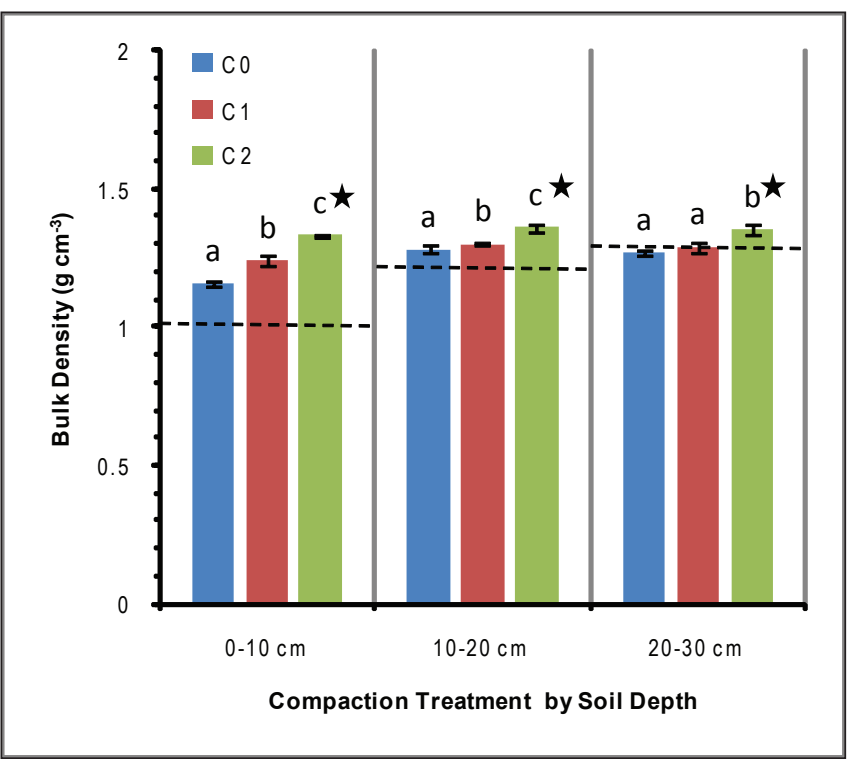

Figure 7.--Means and standard errors for bulk density immediately following application ( $\mathrm{yr} 0$ ) of $\mathrm{C}_{1}$ (medium) and $\mathrm{C}_{2}$ (heavy) compaction treatments, relative to $\mathrm{C}_{0}$ (no additional compaction), for three soil depths on clay loam soil at the Ottawa National Forest. Mean values for each compaction treatment are pooled across all organic matter removal treatments. Bars with common letters indicate means were not significantly different $(p \leq 0.05)$. Significance tests of compaction treatments apply within each soil depth category only. Dashed horizontal lines are mean preharvest bulk density values, pooled across all treatments by depth. Note: comparisons for treatment $\mathrm{C}_{2}$ are approximated by the analysis because $n=1$ for this treatment; the value shown is not a true mean and the standard error used is the estimated value for the comparisons.

\section{Soil Chemical Characteristics}

\section{Loamy Sand Soil}

At year 10, no significant differences $(p>0.05)$ were detected in total carbon or total nitrogen between the control and any compaction or organic matter removal treatment at any depth (Table 2). For most other variables, no significant differences were detected, except CECe and $\mathrm{Ca}$ were significantly lower than control for the $\mathrm{OM}_{2}$ treatment at $0-10 \mathrm{~cm}$ and $\mathrm{Na}$ was significantly greater than control for the $\mathrm{C}_{2}$ treatment at $10-20 \mathrm{~cm}$ (Table 2).

\section{Silt Loam Soil}

At year 10, no significant differences were detected in total carbon or total nitrogen between the control and any compaction or organic matter removal treatment at any depth (Table 3). Moreover, $\mathrm{CECe}, \mathrm{Ca}$, and $\mathrm{Na}$ did

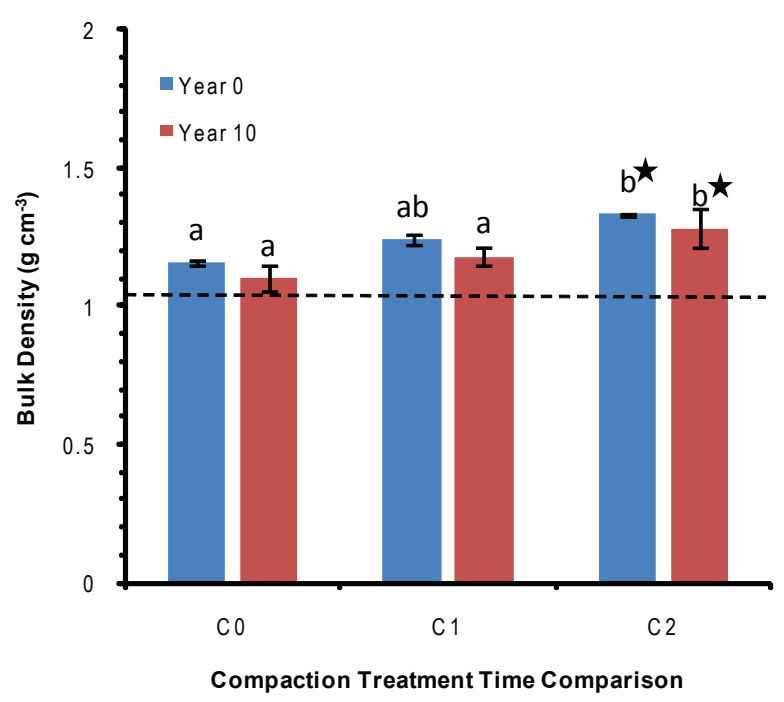

Figure 8.-Means and standard errors for bulk density of compaction treatments at $0-10 \mathrm{~cm}$ immediately after treatment ( $\mathrm{yr} 0$ ) and 10 years after treatment ( $\mathrm{yr} 10)$ for the clay loam soil at the Ottawa National Forest. Bars with common letters indicate means are not significantly different $(p \leq 0.05)$. Dashed horizontal line is the mean preharvest bulk density pooled across all treatments. Compaction treatments are constrained to $\mathrm{OM}_{0}$. Note: comparisons for treatment $\mathrm{C}_{2}$ are approximated by the analysis because $\mathrm{n}=1$ for this treatment; the value shown if not a true mean and the standard error used is the estimated value for the comparisons. not differ between the control and any compaction or organic matter removal treatment at either depth (Table 3). Potasium was significantly lower than the control in the $\mathrm{OM}_{1}$ and $\mathrm{OM}_{2}$ treatments at $10-20 \mathrm{~cm}$, and $\mathrm{Mg}$ was significantly lower for treatments $\mathrm{C}_{1}$ at 0-10 $\mathrm{cm}$ and $\mathrm{C}_{2}$ at $10-20 \mathrm{~cm}$ (Table 3).

\section{Clay Loam Soil}

At year 10, no significant differences were detected in total carbon or total nitrogen between the control and any compaction or organic matter removal treatment at any depth (Table 4). Moreover, CECe, Ca, $\mathrm{K}$, and $\mathrm{Mg}$ did not differ between the control and any compaction or organic matter removal treatment at either depth, while Na was significantly lower than the control at 10-20 cm for both $\mathrm{C}_{1}$ and $\mathrm{OM}_{1}$ treatments (Table 4). 
Table 2.-Means ( \pm standard errors) of soil chemical variables for organic matter removal and compaction treatments and the control at year 10 on loamy sand soil (Huron National Forest).

\begin{tabular}{|c|c|c|c|c|c|c|c|c|}
\hline \multirow[b]{2}{*}{ Treatment $^{\mathrm{a}}$} & \multirow{2}{*}{$\begin{array}{l}\text { Soil depth } \\
\qquad \mathrm{cm}\end{array}$} & CECe & $\mathrm{Ca}$ & $\mathrm{K}$ & $\mathrm{Mg}$ & $\mathrm{Na}$ & Total C & Total N \\
\hline & & \multicolumn{5}{|c|}{$\mathrm{cmol} \mathrm{kg}^{-1}$} & \multicolumn{2}{|c|}{$\mathrm{Mg} \mathrm{ha}^{-1}$} \\
\hline \multirow{3}{*}{$\mathrm{C}_{0}, \mathrm{OM}_{0}$} & $0-10$ & $\begin{array}{c}1.937 \\
\pm 0.389\end{array}$ & $\begin{array}{c}1.518 \\
\pm 0.325\end{array}$ & $\begin{array}{c}0.106 \\
\pm 0.011\end{array}$ & $\begin{array}{c}0.292 \\
\pm 0.063\end{array}$ & $\begin{array}{c}0.021 \\
\pm 0.005\end{array}$ & $16.38 \pm 3.16$ & $0.88 \pm 0.19$ \\
\hline & $10-20$ & $\begin{array}{c}0.630 \\
\pm 0.040\end{array}$ & $\begin{array}{c}0.458 \\
\pm 0.041\end{array}$ & $\begin{array}{c}0.068 \\
\pm 0.008\end{array}$ & $\begin{array}{c}0.097 \\
\pm 0.006\end{array}$ & $\begin{array}{c}0.007 \\
\pm 0.001\end{array}$ & $10.10 \pm 0.70$ & $0.70 \pm 0.03$ \\
\hline & $20-30$ & ----- & ----- & ----- & ----- & ----- & $10.53 \pm 1.06$ & $0.77 \pm 0.04$ \\
\hline \multirow{3}{*}{$\mathrm{OM}_{1}$} & $0-10$ & $\begin{array}{c}1.662 \\
\pm 0.105\end{array}$ & $\begin{array}{c}1.302 \\
\pm 0.104\end{array}$ & $\begin{array}{c}0.087 \\
\pm 0.007\end{array}$ & $\begin{array}{c}0.256 \\
\pm 0.010\end{array}$ & $\begin{array}{c}0.017 \\
\pm 0.007\end{array}$ & $18.10 \pm 1.18$ & $0.99 \pm 0.18$ \\
\hline & $10-20$ & $\begin{array}{c}0.846 \\
\pm 0.142\end{array}$ & $\begin{array}{c}0.648 \\
\pm 0.123\end{array}$ & $\begin{array}{c}0.081 \\
\pm 0.016\end{array}$ & $\begin{array}{c}0.111 \\
\pm 0.025\end{array}$ & $\begin{array}{c}0.005 \\
\pm 0.001\end{array}$ & $11.11 \pm 1.49$ & $0.706 \pm 0.06$ \\
\hline & $20-30$ & ----- & ---- & ----- & ---- & ----- & $9.70 \pm 1.97$ & $0.71 \pm 0.12$ \\
\hline \multirow{3}{*}{$\mathrm{OM}_{2}$} & $0-10$ & $\begin{array}{l}1.278^{*} \\
\pm 0.105\end{array}$ & $\begin{array}{l}0.952^{*} \\
\pm 0.087\end{array}$ & $\begin{array}{c}0.082 \\
\pm 0.007\end{array}$ & $\begin{array}{c}0.222 \\
\pm 0.025\end{array}$ & $\begin{array}{c}0.022 \\
\pm 0.005\end{array}$ & $12.22 \pm 3.03$ & $0.82 \pm 0.20$ \\
\hline & $10-20$ & $\begin{array}{c}0.521 \\
\pm 0.095\end{array}$ & $\begin{array}{c}0.372 \\
\pm 0.097\end{array}$ & $\begin{array}{c}0.071 \\
\pm 0.021\end{array}$ & $\begin{array}{c}0.072 \\
\pm 0.010\end{array}$ & $\begin{array}{c}0.006 \\
\pm 0.003\end{array}$ & $11.28 \pm 1.81$ & $0.76 \pm 0.09$ \\
\hline & $20-30$ & ----- & ----- & ----- & ----- & ----- & $8.84 \pm 0.74$ & $0.66 \pm 0.08$ \\
\hline \multirow{3}{*}{$\mathrm{C}_{1}$} & $0-10$ & $\begin{array}{c}1.677 \\
\pm 0.287\end{array}$ & $\begin{array}{c}1.313 \\
\pm 0.276\end{array}$ & $\begin{array}{c}0.124 \\
\pm 0.017\end{array}$ & $\begin{array}{c}0.225 \\
\pm 0.029\end{array}$ & $\begin{array}{c}0.015 \\
\pm 0.007\end{array}$ & $13.69 \pm 3.37$ & $0.85 \pm 0.07$ \\
\hline & $10-20$ & $\begin{array}{c}0.569 \\
\pm 0.114\end{array}$ & $\begin{array}{c}0.412 \\
\pm 0.103\end{array}$ & $\begin{array}{c}0.063 \\
\pm 0.007\end{array}$ & $\begin{array}{c}0.075 \\
\pm 0.014\end{array}$ & $\begin{array}{c}0.019 \\
\pm 0.004\end{array}$ & $9.09 \pm 0.66$ & $0.79 \pm 0.09$ \\
\hline & $20-30$ & ----- & ----- & ----- & ----- & ----- & $10.33 \pm 0.34$ & $0.73 \pm 0.06$ \\
\hline \multirow{3}{*}{$\mathrm{C}_{2}$} & $0-10$ & $\begin{array}{r}1.459 \\
\pm 0.266\end{array}$ & $\begin{array}{c}1.128 \\
\pm 0.237\end{array}$ & $\begin{array}{c}0.105 \\
\pm 0.018\end{array}$ & $\begin{array}{c}0.219 \\
\pm 0.016\end{array}$ & $\begin{array}{c}0.007 \\
\pm 0.003\end{array}$ & $17.88 \pm 3.03$ & $0.88 \pm 0.12$ \\
\hline & $10-20$ & $\begin{array}{c}0.561 \\
\pm 0.068\end{array}$ & $\begin{array}{c}0.392 \\
\pm 0.069\end{array}$ & $\begin{array}{c}0.071 \\
\pm 0.002\end{array}$ & $\begin{array}{c}0.078 \\
\pm 0.003\end{array}$ & $\begin{array}{l}0.021^{*} \\
\pm 0.002\end{array}$ & $15.06 \pm 2.65$ & $0.92 \pm 0.04$ \\
\hline & $20-30$ & ----- & ----- & ----- & ----- & ----- & $12.01 \pm 0.79$ & $1.10 \pm 0.19$ \\
\hline
\end{tabular}

${ }^{\mathrm{a}} \mathrm{C}_{0}, \mathrm{OM}_{0}$ (control) = no additional compaction and bole only harvest, $\mathrm{C}_{1}=$ medium compaction, $\mathrm{C}_{2}=$ heavy compaction, $\mathrm{OM}_{1}=$ total tree harvest, $\mathrm{OM}_{2}=$ total tree harvest + forest floor removal. Note: organic matter treatment means constrained to $\mathrm{C}_{0}$. Compaction treatment means constrained to $\mathrm{OM}_{0}$.

*Indicates a significant difference from the control $\left(\mathrm{C}_{0}, \mathrm{OM}_{0}\right)$ at $\mathrm{p} \leq 0.05$. 
Table 3.- Means ( \pm standard errors) of soil chemical variables for organic matter removal and compaction treatments and the control at year 10 on silt loam soil (Chippewa National Forest).

\begin{tabular}{|c|c|c|c|c|c|c|c|c|}
\hline \multirow[b]{2}{*}{ Treatment $^{\mathrm{a}}$} & \multirow{2}{*}{$\begin{array}{l}\text { Soil Depth } \\
\qquad \mathrm{cm}\end{array}$} & CECe & $\mathrm{Ca}$ & $\mathrm{K}$ & $\mathrm{Mg}$ & $\mathrm{Na}$ & Total C & Total N \\
\hline & & \multicolumn{5}{|c|}{$\mathrm{cmol} \mathrm{kg}^{-1}$} & \multicolumn{2}{|c|}{$\mathrm{Mg} \mathrm{ha}^{-1}$} \\
\hline \multirow{3}{*}{$\mathrm{C}_{0}, \mathrm{OM}_{0}$} & $0-10$ & $\begin{array}{c}5.403 \\
\pm 0.466\end{array}$ & $\begin{array}{c}4.305 \\
\pm 0.422\end{array}$ & $\begin{array}{c}0.239 \\
\pm 0.011\end{array}$ & $\begin{array}{c}0.831 \\
\pm 0.092\end{array}$ & $\begin{array}{c}0.028 \\
\pm 0.012\end{array}$ & $17.44 \pm 0.62$ & $1.14 \pm 0.05$ \\
\hline & $10-20$ & $\begin{array}{c}3.326 \\
\pm 0.489\end{array}$ & $\begin{array}{c}2.423 \\
\pm 0.364\end{array}$ & $\begin{array}{c}0.199 \\
\pm 0.014\end{array}$ & $\begin{array}{c}0.692 \\
\pm 0.142\end{array}$ & $\begin{array}{c}0.012 \\
\pm 0.005\end{array}$ & $6.58 \pm 0.72$ & $0.63 \pm 0.02$ \\
\hline & $20-30$ & ----- & ----- & ----- & ----- & ----- & $3.33 \pm 1.05$ & $0.48 \pm 0.06$ \\
\hline \multirow{3}{*}{$\mathrm{OM}_{1}$} & $0-10$ & $\begin{array}{c}4.358 \\
\pm 1.150\end{array}$ & $\begin{array}{c}4.457 \\
\pm 1.101\end{array}$ & $\begin{array}{c}0.195 \\
\pm 0.010\end{array}$ & $\begin{array}{c}0.686 \\
\pm 0.058\end{array}$ & $\begin{array}{c}0.007 \\
\pm 0.004\end{array}$ & $16.33 \pm 2.14$ & $1.08 \pm 0.08$ \\
\hline & $10-20$ & $\begin{array}{c}2.873 \\
\pm 0.322\end{array}$ & $\begin{array}{c}2.197 \\
\pm 0.312\end{array}$ & $\begin{array}{l}0.142^{*} \\
\pm 0.007\end{array}$ & $\begin{array}{c}0.522 \\
\pm 0.051\end{array}$ & $\begin{array}{c}0.012 \\
\pm 0.004\end{array}$ & $5.01 \pm 0.26$ & $0.58 \pm 0.05$ \\
\hline & $20-30$ & ----- & ----- & ----- & ----- & ----- & $2.42 \pm 0.70$ & $0.54 \pm 0.03$ \\
\hline \multirow{3}{*}{$\mathrm{OM}_{2}$} & $0-10$ & $\begin{array}{c}5.467 \\
\pm 0.734\end{array}$ & $\begin{array}{c}3.940 \\
\pm 0.665\end{array}$ & $\begin{array}{c}0.206 \\
\pm 0.023\end{array}$ & $\begin{array}{c}0.647 \\
\pm 0.057\end{array}$ & $\begin{array}{c}0.007 \\
\pm 0.004\end{array}$ & $16.85 \pm 1.83$ & $1.12 \pm 0.11$ \\
\hline & $10-20$ & $\begin{array}{c}2.813 \\
\pm 0.335\end{array}$ & $\begin{array}{c}2.108 \\
\pm 0.290\end{array}$ & $\begin{array}{l}0.151^{*} \\
\pm 0.020\end{array}$ & $\begin{array}{c}0.531 \\
\pm 0.058\end{array}$ & $\begin{array}{c}0.023 \\
\pm 0.004\end{array}$ & $7.65 \pm 2.58$ & $0.62 \pm 0.02$ \\
\hline & $20-30$ & ----- & ----- & ----- & ----- & ----- & $1.97 \pm 0.31$ & $0.47 \pm 0.03$ \\
\hline \multirow{3}{*}{$\mathrm{C}_{1}$} & $0-10$ & $\begin{array}{c}4.725 \\
\pm 0.500\end{array}$ & $\begin{array}{c}3.910 \\
\pm 0.480\end{array}$ & $\begin{array}{c}0.220 \\
\pm 0.011\end{array}$ & $\begin{array}{l}0.572^{*} \\
\pm 0.025\end{array}$ & $\begin{array}{c}0.023 \\
\pm 0.010\end{array}$ & $15.95 \pm 3.40$ & $1.17 \pm 0.15$ \\
\hline & $10-20$ & $\begin{array}{c}2.928 \\
\pm 0.281\end{array}$ & $\begin{array}{c}2.182 \\
\pm 0.209\end{array}$ & $\begin{array}{c}0.157 \\
\pm 0.013\end{array}$ & $\begin{array}{c}0.553 \\
\pm 0.064\end{array}$ & $\begin{array}{c}0.037 \\
\pm 0.013\end{array}$ & $4.75 \pm 1.59$ & $0.67 \pm 0.10$ \\
\hline & $20-30$ & ----- & ----- & ----- & ----- & ----- & $2.46 \pm 0.15$ & $0.49 \pm 0.05$ \\
\hline \multirow{3}{*}{$\mathrm{C}_{2}$} & $0-10$ & $\begin{array}{c}5.573 \\
\pm 1.053\end{array}$ & $\begin{array}{c}4.637 \\
\pm 0.980\end{array}$ & $\begin{array}{c}0.251 \\
\pm 0.033\end{array}$ & $\begin{array}{c}0.669 \\
\pm 0.062\end{array}$ & $\begin{array}{c}0.016 \\
\pm 0.009\end{array}$ & $18.27 \pm 2.40$ & $1.19 \pm 0.14$ \\
\hline & $10-20$ & $\begin{array}{c}2.841 \\
\pm 0.378\end{array}$ & $\begin{array}{c}2.195 \\
\pm 0.367\end{array}$ & $\begin{array}{c}0.157 \\
\pm 0.011\end{array}$ & $\begin{array}{l}0.461^{*} \\
\pm 0.041\end{array}$ & $\begin{array}{c}0.028 \\
\pm 0.010\end{array}$ & $8.44 \pm 2.77$ & $0.69 \pm 0.08$ \\
\hline & $20-30$ & ----- & ----- & ----- & ----- & ----- & $2.35 \pm 0.14$ & $0.45 \pm 0.02$ \\
\hline
\end{tabular}

${ }^{\mathrm{a}} \mathrm{C}_{0}, \mathrm{OM}_{0}($ control $)=$ no additional compaction and bole only harvest, $\mathrm{C}_{1}=$ medium compaction, $\mathrm{C}_{2}=$ heavy compaction, $\mathrm{OM}_{1}=$ total tree harvest, $\mathrm{OM}_{2}=$ total tree harvest + forest floor removal. Note: organic matter treatment means constrained to $\mathrm{C}_{0}$. Compaction treatment means constrained to $\mathrm{OM}_{0}$.

*Indicates a significant difference from the control $\left(\mathrm{C}_{0}, \mathrm{OM}_{0}\right)$ at $\mathrm{p} \leq 0.05$. 
Table 4.-Means ( \pm standard errors) of soil chemical variables for organic matter removal and compaction treatments and the control at year 10 on clay loam soil (Ottawa National Forest).

\begin{tabular}{|c|c|c|c|c|c|c|c|c|}
\hline \multirow[b]{2}{*}{ Treatment $^{a}$} & \multirow{2}{*}{$\begin{array}{c}\text { Soil Depth } \\
\qquad \mathrm{cm}\end{array}$} & CECe & $\mathrm{Ca}$ & $\mathrm{K}$ & $\mathrm{Mg}$ & $\mathrm{Na}$ & Total C & Total N \\
\hline & & \multicolumn{5}{|c|}{$\mathrm{cmol} \mathrm{kg}^{-1}$} & \multicolumn{2}{|c|}{$\mathrm{Mg} \mathrm{ha}^{-1}$} \\
\hline \multirow{3}{*}{$\mathrm{C}_{0}, \mathrm{OM}_{0}$} & $0-10$ & $\begin{array}{c}8.622 \\
\pm 0.935\end{array}$ & $\begin{array}{c}6.600 \\
\pm 0.742\end{array}$ & $\begin{array}{c}0.329 \\
\pm 0.043\end{array}$ & $\begin{array}{c}1.686 \\
\pm 0.232\end{array}$ & $\begin{array}{c}0.007 \\
\pm 0.001\end{array}$ & $28.68 \pm 3.79$ & $1.52 \pm 0.15$ \\
\hline & $10-20$ & $\begin{array}{r}11.072 \\
\pm 1.394\end{array}$ & $\begin{array}{c}7.600 \\
\pm 0.980\end{array}$ & $\begin{array}{c}0.450 \\
\pm 0.046\end{array}$ & $\begin{array}{c}2.906 \\
\pm 0.368\end{array}$ & $\begin{array}{c}0.117 \\
\pm 0.016\end{array}$ & $10.67 \pm 0.27$ & $0.81 \pm 0.03$ \\
\hline & $20-30$ & ----- & ----- & ----- & ----- & ----- & $7.62 \pm 0.09$ & $0.66 \pm 0.03$ \\
\hline \multirow{3}{*}{$\mathrm{OM}_{1}$} & $0-10$ & $\begin{array}{c}7.963 \\
\pm 0.301\end{array}$ & $\begin{array}{c}5.880 \\
\pm 0.248\end{array}$ & $\begin{array}{c}0.335 \\
\pm 0.006\end{array}$ & $\begin{array}{c}1.735 \\
\pm 0.048\end{array}$ & $\begin{array}{c}0.012 \\
\pm 0.004\end{array}$ & $30.22 \pm 3.43$ & $1.67 \pm 0.12$ \\
\hline & $10-20$ & $\begin{array}{l}10.830 \\
\pm 0.342\end{array}$ & $\begin{array}{c}7.240 \\
\pm 0.201\end{array}$ & $\begin{array}{c}0.439 \\
\pm 0.016\end{array}$ & $\begin{array}{c}3.083 \\
\pm 0.137\end{array}$ & $\begin{array}{l}0.067^{*} \\
\pm 0.010\end{array}$ & $11.55 \pm 1.09$ & $0.89 \pm 0.06$ \\
\hline & $20-30$ & ---- & ---- & ----- & ----- & ----- & $8.18 \pm 0.47$ & $0.69 \pm 0.02$ \\
\hline \multirow{3}{*}{$\mathrm{OM}_{2}$} & $0-10$ & $\begin{array}{c}8.521 \\
\pm 0.565\end{array}$ & $\begin{array}{c}6.167 \\
\pm 0.433\end{array}$ & $\begin{array}{c}0.370 \\
\pm 0.020\end{array}$ & $\begin{array}{c}1.972 \\
\pm 0.134\end{array}$ & $\begin{array}{c}0.012 \\
\pm 0.006\end{array}$ & $31.18 \pm 3.59$ & $1.67 \pm 0.17$ \\
\hline & $10-20$ & $\begin{array}{l}10.700 \\
\pm 1.106\end{array}$ & $\begin{array}{c}7.200 \\
\pm 0.757\end{array}$ & $\begin{array}{c}0.427 \\
\pm 0.018\end{array}$ & $\begin{array}{c}2.983 \\
\pm 0.312\end{array}$ & $\begin{array}{c}0.089 \\
\pm 0.026\end{array}$ & $12.40 \pm 1.50$ & $0.94 \pm 0.03$ \\
\hline & $20-30$ & ----- & ----- & ----- & ----- & ----- & $9.31 \pm 1.35$ & $0.67 \pm 0.01$ \\
\hline \multirow{3}{*}{$\mathrm{C}_{1}$} & $0-10$ & $\begin{array}{c}7.515 \\
\pm 0.259\end{array}$ & $\begin{array}{c}5.425 \\
\pm 0.125\end{array}$ & $\begin{array}{c}0.303 \\
\pm 0.029\end{array}$ & $\begin{array}{c}1.771 \\
\pm 0.113\end{array}$ & $\begin{array}{c}0.017 \\
\pm 0.001\end{array}$ & $32.78 \pm 3.39$ & $1.85 \pm 0.08$ \\
\hline & $10-20$ & $\begin{array}{l}10.986 \\
\pm 0.796\end{array}$ & $\begin{array}{c}7.225 \\
\pm 0.525\end{array}$ & $\begin{array}{c}0.405 \\
\pm 0.018\end{array}$ & $\begin{array}{c}3.275 \\
\pm 0.242\end{array}$ & $\begin{array}{l}0.081^{*} \\
\pm 0.011\end{array}$ & $10.27 \pm 0.59$ & $0.95 \pm 0.01$ \\
\hline & $20-30$ & ----- & ----- & ----- & ----- & ----- & $7.49 \pm 0.07$ & $0.67 \pm 0.03$ \\
\hline \multirow{3}{*}{$\mathrm{C}_{2}{ }^{\mathrm{b}}$} & $0-10$ & 8.034 & 5.750 & 0.362 & 1.908 & 0.014 & 26.35 & 1.54 \\
\hline & $10-20$ & 12.218 & 8.20 & 0.456 & 3.483 & 0.078 & 10.09 & 0.82 \\
\hline & $20-30$ & ----- & ----- & ----- & ----- & ----- & 8.81 & 0.75 \\
\hline
\end{tabular}

${ }^{\mathrm{a}} \mathrm{C}_{0}, \mathrm{OM}_{0}$ (control) $=$ no additional compaction and bole only harvest, $\mathrm{C}_{1}=$ medium compaction, $\mathrm{C}_{2}=$ heavy compaction, $\mathrm{OM}_{1}=$ total tree harvest, $\mathrm{OM}_{2}=$ total tree harvest + forest floor removal. Note: organic matter treatment means constrained to $\mathrm{C}_{0}$. Compaction treatment means constrained to $\mathrm{OM}_{0}$.

bValues are not means of replicates as $\mathrm{C}_{2} \mathrm{OM}_{0}$ at Ottawa had only 1 replicate $(n=1)$.

*Indicates a significant difference from the control $\left(\mathrm{C}_{0}, \mathrm{OM}_{0}\right)$ at $\mathrm{p} \leq 0.05$. 


\section{Vegetation Responses}

\section{Loamy Sand Soil}

Both total aboveground woody biomass and aspen biomass at year 10 were significantly lower for the $\mathrm{OM}_{2}$ treatment than the control. Aspen biomass was significantly greater than the control for $\mathrm{C}_{1}$ treatment and total biomass was marginally higher than the control for this treatment. Herbaceous biomass, total stem density, and aspen stem density did not differ significantly between the control and any compaction or organic matter removal treatments

(Fig. 9).

\section{Silt Loam Soil}

Both total aboveground woody biomass and mean aspen biomass were significantly less for the $\mathrm{OM}_{2}$,
$\mathrm{C}_{1}$ and $\mathrm{C}_{2}$ treatments than for the control. $\mathrm{C}_{1}$ and $\mathrm{C}_{2}$ had significantly higher herbaceous biomass than the control and $\mathrm{C}_{2}$ also had significantly lower total stem density compared to control (Fig. 10).

\section{Clay Loam Soil}

On the clay loam soil, the $\mathrm{C}_{1}$ treatment had a significantly higher total biomass compared to the control. Total biomass and aspen biomass were significantly higher than control for the $\mathrm{OM}_{2}$ treatment. Herbaceous biomass, total stem density, and aspen stem density were not significantly different from the control for any of the treatments (Fig. 11).

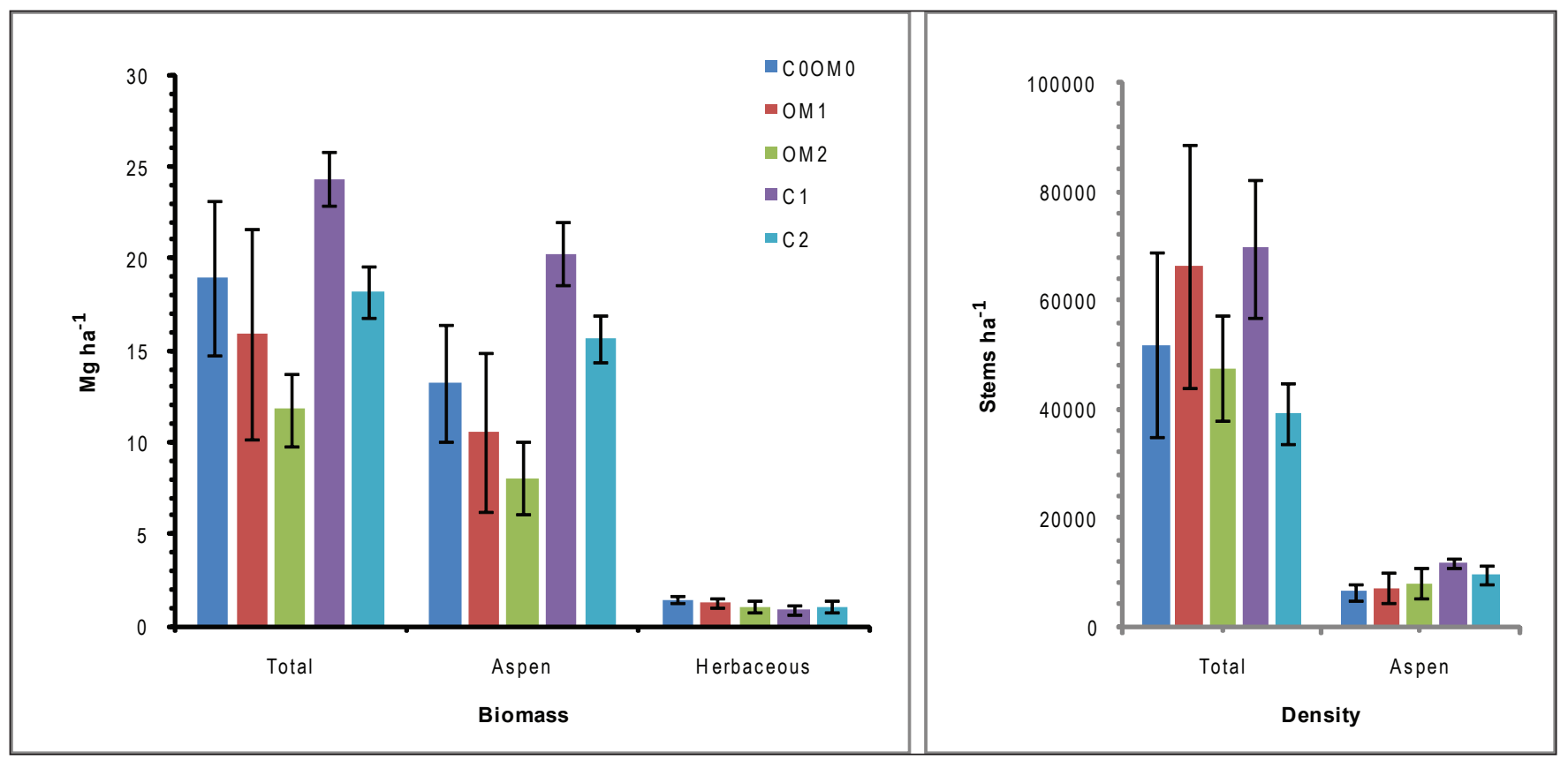

Figure 9.- Means and standard errors for aboveground biomass and density of vegetation groups 10 years after application of $\mathrm{OM}_{1}$ (whole-tree harvest), $\mathrm{OM}_{2}$ (whole-tree harvest plus forest floor removal), $\mathrm{C}_{1}$ (medium), and $\mathrm{C}_{2}$ (heavy) compaction treatments, relative to $\mathrm{C}_{0} \mathrm{OM}_{0}$ (control: bole only harvest and no additional compaction) on loamy sand soil at the Huron National Forest. Bars with an asterisk indicate means were significantly different from the control $(p \leq 0.05)$. 


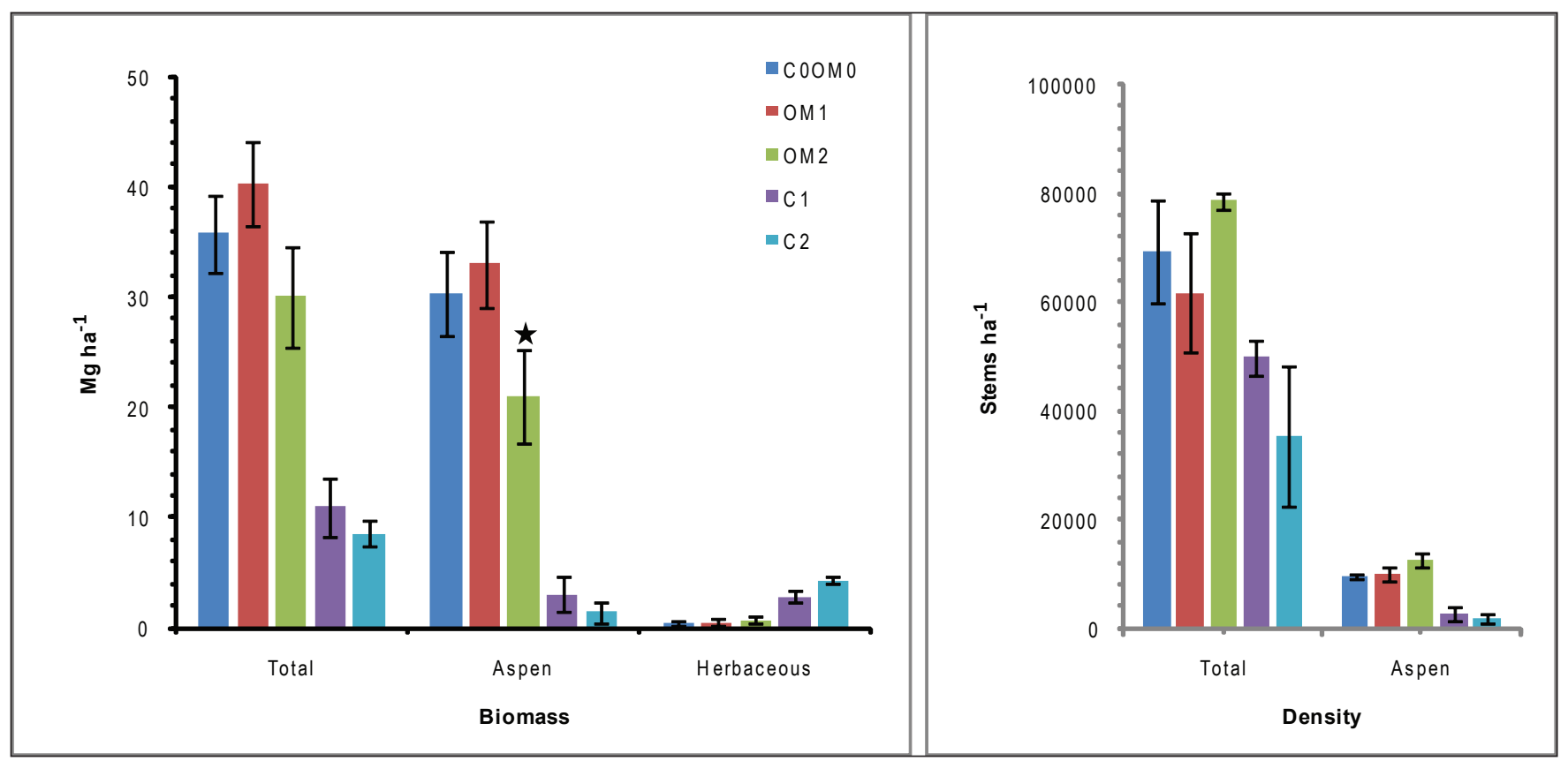

Figure 10.-Means and standard errors for aboveground biomass and density of vegetation groups 10 years after application of $\mathrm{OM}_{1}$ (whole-tree harvest), $\mathrm{OM}_{2}$ (whole-tree harvest plus forest floor removal), $\mathrm{C}_{1}$ (medium), and $\mathrm{C}_{2}$ (heavy) compaction treatments, relative to $\mathrm{C}_{0} \mathrm{OM}_{0}$ (control: bole only harvest and no additional compaction) on silt loam soil at the Chippewa National Forest. Bars with an asterisk indicate means were significantly different from the control $(p \leq 0.05)$.

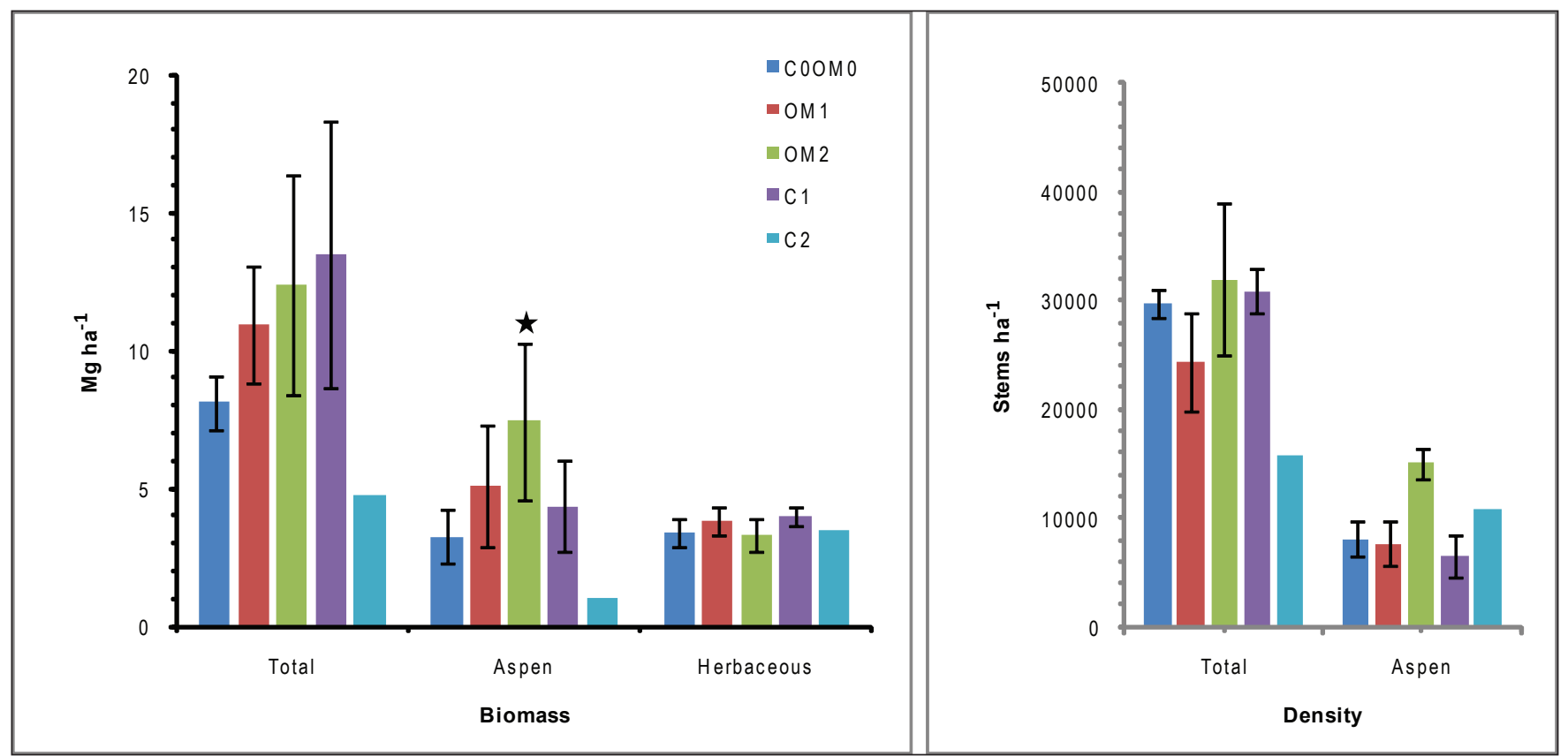

Figure 11.-Means and standard errors for aboveground biomass and density of vegetation groups 10 years after application of $\mathrm{OM}_{1}$ (whole-tree harvest), $\mathrm{OM}_{2}$ (whole-tree harvest plus forest floor removal), $\mathrm{C}_{1}$ (medium), and $\mathrm{C}_{2}$ (heavy) compaction treatments, relative to COOMO (control: bole only harvest and no additional compaction) on clay loam soil at the Ottawa National Forest. Bars with an asterisk indicate means were significantly different from the control $(p \leq 0.05)$. Note: $n=1$ for treatment $\mathrm{C}_{2}$; it was not included in the analysis. 


\section{DISCUSSION}

In this study, we asked if there was an effect from organic matter removal or soil compaction on soil physical and chemical properties, 10 years after treatment application, and at what level of treatment an effect was evident. The compaction treatments increased soil bulk density above preharvest levels for all three soil types and at all soil depths, but particularly at $0-10 \mathrm{~cm}$. Generally, the increase in bulk density paralleled the increasing intensity of the compaction treatment. Moreover, bulk densities generally remained above pretreatment levels on all soil types, 10 years after treatment, particularly at $0-10$ $\mathrm{cm}$. However, by year 10 , bulk density at $0-10 \mathrm{~cm}$ decreased and compaction treatments were no longer significantly different from control, except on the clay loam soil where the high compaction treatment remained significantly greater than the no-additional compaction treatment. Bulk density at the deeper soil depths remained significantly greater than control for both compaction treatments on the loamy sand soil. Overall, by year 10, organic matter removal treatments had little effect on the soil properties we examined on any of the soil types.

Soil chemical responses were generally minimal and specific to a soil texture. On the loamy sand soil (Huron National Forest), CECe and Ca were significantly lower at the $0-10 \mathrm{~cm}$ soil depth with total tree plus forest floor removal, relative to the control. It appears that the removal of forest floor organic matter, in addition to total tree harvest, may result in lower Ca concentrations in the upper most $10 \mathrm{~cm}$ in the loamy sand soil. This may result in decreased inputs of $\mathrm{Ca}$ to the soil, after removal of the forest floor, and/or increased leaching for a short period of time. On the silt loam soil (Chippewa National Forest), $\mathrm{Mg}$ was significantly less for the moderate compaction treatment at $0-10 \mathrm{~cm}$ and the heavy compaction treatment at $10-20 \mathrm{~cm}$, while $\mathrm{K}$ was significantly less than the control with total tree plus forest floor removal at $10-20 \mathrm{~cm}$. On the clay loam soil (Ottawa National Forest), only one soil chemical measure $\left(\mathrm{Na}\right.$ in $\mathrm{C}_{1}$ at $10-20 \mathrm{~cm}$ ) differed significantly from the control at year 10 .

Is there an effect of treatment on vegetation productivity and abundance after 10 years and at what level of organic matter removal or compaction is an effect evident? On the loamy sand soil (Huron National Forest), both total woody and aspen biomass were significantly less with total tree harvest plus forest floor removal than the control, but biomass in the total tree harvest treatment did not differ from the control. Possibly, the decrease in biomass resulted from the reduction in $\mathrm{Ca}$ that was also noted in this treatment. Also at year 10, moderate compaction on the loamy sand soil significantly increased aspen biomass compared to the control. A similar response for aspen biomass was found at year 5 and was attributed to increased water-holding capacity due to conversion of some macropores to micropore space with moderate compaction (Stone et al. 1998). This is consistent with results from an analysis of other LTSP sites, where biomass production increased with compaction on sand soils (Powers et al. 2005), presumably due to improved moisture status. However, our data also show that heavy compaction did not result in further improvements in moisture status above moderate compaction.

On the silt loam soil (Chippewa National Forest), total biomass and aspen biomass were significantly less than the control with total tree harvest plus forest floor removal and with both levels of compaction. Moreover, total stem density was lower than the control on the highest compaction treatment. Neither total biomass nor aspen biomass differed from the control with total tree harvest alone. The reduction of biomass with total tree plus forest floor removal is probably not due to the reduction in $\mathrm{K}$ with this treatment, as $\mathrm{K}$ limitations are rare in most forests. Reductions in biomass with the compaction treatments likely was due to reductions in macropores, increased root restriction, reduced water infiltration rates, and altered gaseous exchange (Alban 1991, Greacen and Sands 1980). Moreover, the timing of the compaction treatments at this site may have played a significant role in the biomass reduction noted. Compaction treatments were applied in late spring after aspen suckering had already begun and resulted in some destruction of these suckers by the compaction equipment (Stone 2001, 2002, Stone and Kabzems 2002). The extent to which this may have impacted aspen resuckering and subsequent biomass growth may have been significant. While application of compaction treatments after aspen suckering likely 
had some impact on aspen regrowth, it is clear that total biomass and aspen biomass were greatly reduced by both moderate and high compaction, likely due to increased bulk densities with these treatments, which in turn may have resulted in reduced aeration and moisture availability. Herbaceous biomass at year 10 was significantly greater on the two compaction treatments and may reflect reduced shading and competition with less woody vegetation on these treatments.

On the clay loam soil (Ottawa National Forest), total tree harvest with forest floor removal significantly increased both total and aspen biomass, while total tree harvesting alone did not differ significantly from main bole only harvesting. The explanation for this is not apparent. Moderate compaction significantly increased total biomass, suggesting that this level of compaction may have improved moisture status. Heavy compaction appeared to reduce both total and aspen biomass relative to the control, although there was only one replicate for this later treatment, so comparisons should be made with caution. However, the latter result is consistent with results from an analysis of other LTSP sites, which showed that biomass production generally declined with high compaction on clay soils (Powers et al. 2005). One explanation for increased aboveground biomass production with both the total tree harvest plus forest floor removal and moderate compaction treatments is that growth of individual aspen suckers may have been stimulated by the application of these treatments, while competition by less disturbance-tolerant species may have been reduced. In contrast, the heavy compaction treatment, with increased bulk density at $0-10 \mathrm{~cm}$, may have damaged and destroyed many plant propagules, including tree roots.

\section{Management Implications}

If main bole harvest with no additional compaction is the standard against which to judge other treatments, then the tenth year results for aspen forests suggest that all three soil types can tolerate total tree harvest, with no additional compaction, without significant reductions in total woody or aspen biomass production, as long as there is no additional compaction. The addition of forest floor removal to the total tree harvest resulted in negative impacts on biomass production for the loamy sand and silt loam soils, but had significant positive effects on the clay loam soil. The caveat for these conclusions is that they are based on relatively short-term (10 years) data; potentially, results could differ in future years. However, our results are supported by a study comparing main bole and whole-tree harvesting in other aspen ecosystems (Alban and Perala 1988), in which neither treatment negatively impacted soil properties in the short-term ( 8 years or less), even though whole-tree harvesting removed as much as 40 percent of the available ecosystem $\mathrm{Ca}$ and significant amounts of other nutrients in the upper mineral soil and forest floor. In Alban and Perala's study, annual litterfall mass returned to preharvest levels within 6 years and there were no differences between the two harvesting systems in forest floor weight, vegetative regrowth, and soil carbon.

Our results suggest that heavy compaction is likely is be detrimental to woody plant production, at least in the short term. Moderate compaction may actually stimulate production on some soils (loamy sand and clay loam). However, we do not recommend that controlled compaction be used as a tool to improve productivity, as controlling the level of application would be difficult. Rather, the goal should be to minimize compaction to the extent possible in all cases.

The long-term impacts on site quality and productivity of whole-tree harvesting and compaction remain largely unknown. For example, long-term impacts for soil cation depletion, for example Ca reduction on the loamy sand soil, remain unknown given that the aspen stands we studied are still relatively young and nutrient demanding (Alban and Perala 1990). Shorter rotations with more frequent entries for whole-tree tree harvests for biomass feedstocks add to that uncertainty of response and the need for caution. Long-term research such as the LTSP program is essential for increasing our understanding of these responses.

\section{ACKNOWLEDGMENTS}

We are grateful to the Forest Service soil scientists that have supported this work over the last decade, especially Sarah Mase, Joe Gates, Jim Barrot, Neil Babik, and Dave Shadis. We thank Mary Beth Adams and Randy Kolka for helpful comments on an earlier version of this report and John Stanovick for statistical support. 


\section{LITERATURE CITED}

Alban, D.H. 1991. The impact of aspen harvesting on site productivity. In: Navratil, S.; Chapman, P.B., eds. Aspen management for the 21st century: proceedings of the symposium; 1990 November 20-21; Edmonton, Alberta: Forestry Canada Northwest Regional Northern Forest Center and Poplar Council: 71-76.

Alban, D.H.; Perala, D.A. 1990. Impact of aspen timber harvesting on soils. In: Gessel, S.P.; Lactate, D.S.; Weetman, G.F.; Powers, R.F., eds. Sustained productivity of forest soils: proceedings of the 7th North American forest soils conference: 1988 July 24-28; Vancouver, British Columbia: University of British Columbia, Faculty of Forestry Publication: 377-391.

Ballard, T.M. 2000. Impacts of forest management on northern forest soils. Forest Ecology and Management. 133: 37-42.

Greacen, E.L.; Sands, R. 1980. Compaction of forest soils: a review. Australian Journal of Soil Research. 18: $163-189$.

Grigal, D.F. 2000. Effects of extensive forest management on soil productivity. Forest Ecology and Management. 138: 167-185.

Hendrickson, O.Q.; Chatarpaul, L.; Burgess, D. 1989. Nutrient cycling following whole-tree and conventional harvest in northern mixed forest. Canadian Journal of Forest Research. 19: 725-735.

Littell, R.C.; Milliken, G.A.; Stroup, W.W.; Wolfinger, R.D. 1996. SAS system for mixed models. Cary, NC: SAS Institute. 633 p.

Lugo, A.E.; Brown, S.L.; Dodson, R.; Smith, T.S.; Shugart, H.H. 1999. Special paper: the Holdridge life zones of the conterminous United States in relation to ecosystem mapping. Journal of Biogeography. 26: 1025-1038.
Page-Dumroese, D.; Jurgensen, M.; Elliot, W.;

Rice, T.; Nesser, J.; Collins, T.; Meurisse, R. 2000. Soil quality standards and guidelines for forest sustainability in northwestern North America. Forest Ecology and Management. 138: 445-462.

Perala, D.A.; Alban, D.H. 1993. Allometric biomass estimators for aspen-dominated ecosystems in the upper Great Lakes. Res. Pap. NC-314. St. Paul, MN: U.S. Department of Agriculture, Forest Service, North Central Forest Experiment Station. $42 \mathrm{p}$.

Powers, R.F. 1999. On the sustainable productivity of planted forests. New Forests. 17: 263-306.

Powers, R.F. 2006. Long-term soil productivity: genesis of the concept and principles behind the program. Canadian Journal of Forest Research. 36: 519-528.

Powers, R.F.; Alban, D.H.; Miller, G.H.; Tiarks, A.E. 1990a. A soils research approach to evaluating management impacts on long-term productivity. In: Dyck, W.J.; Mees, C.A., eds. Impact of intensive harvesting on forest site productivity. Forestry Research Institute Bulletin No. 159. Rotorua, New Zealand: Forestry Research Institute: 67-99.

Powers, R.F.; Alban, D.H.; Miller, R.E.; Tiarks, A.E.; Wells, C.G.; Avers, P.E.; Cline, R.G.; Fitzgerald, R.O.; Loftus, N.S., Jr. 1990b. Sustaining site productivity in North American forests: problems and prospects. In: Gessel, S.P.; Lactate, D.S.; Weetman, G.F.; Powers, R.F., eds. Sustained productivity of forest soils: proceedings of the 7th North American forest soils conference: 1988 July 24-28; Vancouver, British Columbia: University of British Columbia, Faculty of Forestry Publication: 49-79. 
Powers, R.F.; Sanchez, F.G; Scott, D.A.; PageDumroese, D. 2004. The North American long-term soil productivity experiment: coast-to-coast findings from the first decade. In: Shepperd, W.D.; Eskew, L.G., compilers. Silviculture in special places: proceedings of the National Silviculture Workshop; 2003 September 8-11: Granby, CO. Proceedings RMRS-P-34. Fort Collins, CO: U.S. Department of Agriculture, Forest Service, Rocky Mountain Research Station: 191-206.

Powers, R.F.; Scott, D.A.; Sanchez, F.G.; Voldseth, R.A.; Page-Dumroese, D.; Elioff, J.D.; Stone, D.M. 2005. The North American long-term soil productivity experiment: findings from the first decade of research. Forest Ecology and Management. 220: 31-50.

Pritchett, W.L.; Fisher, R.F. 1987. Properties and Management of Forest Soils, 2nd edition. Hoboken, NJ: John Wiley \& Sons. 494 p.

Ross, D.S. 1995. Recommended methods for determining soil cation exchange capacity. In: Sims, J.T.; Wolf, A., eds. Recommended soil testing procedures for the northeastern United States. Northeast Regional Publication No. 493. Newark, DE: Agricultural Experiment Station, University of Delaware: 62-70.

SAS Institute Inc. 1999. SAS for Windows version 8. Cary, NC: SAS Institute Inc. 357 p.

Schulte, L.A.; Mladenoff, D.J.; Crow, T.R.; Merrick, L.C.; Cleland, D.T. 2007. Homogenization of northern U.S. Great Lakes forests due to land use. Landscape Ecology. 22: 1089-1103.

Spilke, J.; Piepho, H.P.; Hu, X. 2005. Analysis of unbalanced data by mixed linear models using the MIXED procedure of the SAS system. Journal of Agronomy and Crop Science. 191: 47-54.
Stone, D.M.; Gates, J.A.; Elioff, J.D. 1998. Are we maintaining aspen productivity on loamy sand soils? In: ZumBahlen, B.; Ek, A.R., eds. Improving forest productivity for timber: proceedings of the conference; 1998 December 1-3; Minneapolis, MN: Department of Forest Resources, University of Minnesota: 177-184.

Stone, D.M. 2001. Sustaining aspen productivity in the lake states. In: Shepperd, W.D.; Binkley, D.; Bartos, D.L.; Stohlgren, T.J.; Eskew, L.G., compilers. Sustaining aspen in western landscapes. Proceedings RMRS-P-18. Fort Collins, CO: U.S. Department of Agriculture, Forest Service, Rocky Mountain Research Station: 47-59.

Stone, D.M. 2002. Lake states aspen productivity following compaction and organic matter removal. In: Parker, S.; Hummel, S.S., compilers. Beyond 2001: A silvicultural odyssey to sustaining terrestrial and aquatic ecosystems: proceedings of the 2001 National Silvicultural Workshop; 2001 May 6-10; Hood River, OR. Gen. Tech. Rep. PNW-546. Portland, OR: U.S. Department of Agriculture, Forest Service, Pacific Northwest Research Station: 59-67.

Stone, D.M.; Kabzems, R. 2002. Aspen development on similar soils in Minnesota and British Columbia after compaction and forest floor removal. The Forestry Chronicle. 78: 886-891.

Tiarks, A.E.; Buford, M.A.; Powers, R.F.; Ragus, J.F.; Page-Dumroese, D.S.; Ponder, F., Jr.; Stone, D. 1997. North American long-term soil productivity research program. In: Communicating the role of silviculture in managing the National Forests: proceedings of the national silvicultural workshop; 1997 May 19-22; Warren, PA. Gen. Tech. Rep. NE-238. Radnor, PA: U.S. Department of Agriculture Forest Service, Northeastern Forest Experiment Station: 140-147.

Walmsley, J.D.; Jones, D.L.; Reynolds, B.; Price, M.H.; Healey, J.R. 2009. Whole tree harvesting can reduce second rotation forest productivity. Forest Ecology and Management. 257: 1104-1111. 
Wolf, A.; Beegle, D. 1995. Recommended soil tests for macronutrients: Phosphorus, potassium, calcium, and magnesium. In: Sims, J.T.; Wolf, A., eds. Recommended soil testing procedures for the northeastern United States. Northeast Regional Publication No. 493. Newark, DE: Agricultural Experiment Station, University of Delaware: 71-83.
Zabowski, D.; Skinner, M.F.; Rygiewicz, P.T. 1994. Timber harvesting and long-term productivity: weathering processes and soil disturbance. Forest Ecology and Management. 66: 55-68. 
Voldseth, Richard; Palik, Brian; Elioff, John. 2011. Ten-year Results from the Long-term Soil Productivity Study in Aspen Ecosystems of the Northern Great Lakes Region. Res. Pap. NRS-17. Newtown Square, PA: U.S.

Department of Agriculture, Forest Service, Northern Research Station. 20 p.

Impacts of organic matter removal and compaction on soil properties and productivity are reported from the first 10 years of the Long-Term Soil Productivity Study in Great Lakes aspen ecosystems. Organic matter removal treatments included main bole, total tree harvest, and total tree harvest with forest floor removal. Compaction treatments included minimal compaction, moderate, and heavy compaction. Treatments were replicated on a clay loam, silt loam, and loamy sand soils. Compaction treatments on all soils increased bulk density above preharvest levels. In most cases, bulk density at year 10 was still above preharvest levels. Total carbon, nitrogen, and cations showed little or no impact from treatment. Compaction and organic matter removal impacted aboveground productivity, however the responses were variable. Aboveground production declined on the loam soil with moderate and heavy compaction. Production increased with moderate compaction on the loamy sand and clay loam soils, but significantly decreased with heavy compaction on clay loam soil. Total tree harvest with forest floor removal reduced production on the loamy sand and loam soils, while it increased production on the clay loam soil. Results from this study suggest that heavy compaction and/or high organic matter removals are detrimental to sustaining forest productivity.

KEY WORDS: Long-term soil productivity (LTSP), whole-tree harvesting, biomass harvesting, bioenergy, trembling aspen, soil compaction, organic matter removal, harvesting impacts

The U.S. Department of Agriculture (USDA) prohibits discrimination in all its programs and activities on the basis of race, color, national origin, age, disability, and where applicable, sex, marital status, familial status, parental status, religion, sexual orientation, genetic information, political beliefs, reprisal, or because all or part of an individual's income is derived from any public assistance program. (Not all prohibited bases apply to all programs.) Persons with disabilities who require alternative means for communication of program information (Braille, large print, audiotape, etc.) should contact USDA's TARGET Center at 202-720-2600 (voice and TDD). To file a complaint of discrimination, write USDA, Director, Office of Civil Rights, 1400 Independence Avenue SW, Washington, DC 20250-9410, or call 800-795-3272 (voice) or 202-720-6384 (TDD). USDA is an equal opportunity provider and employer.

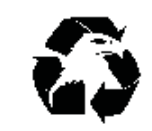

Printed on recycled paper 


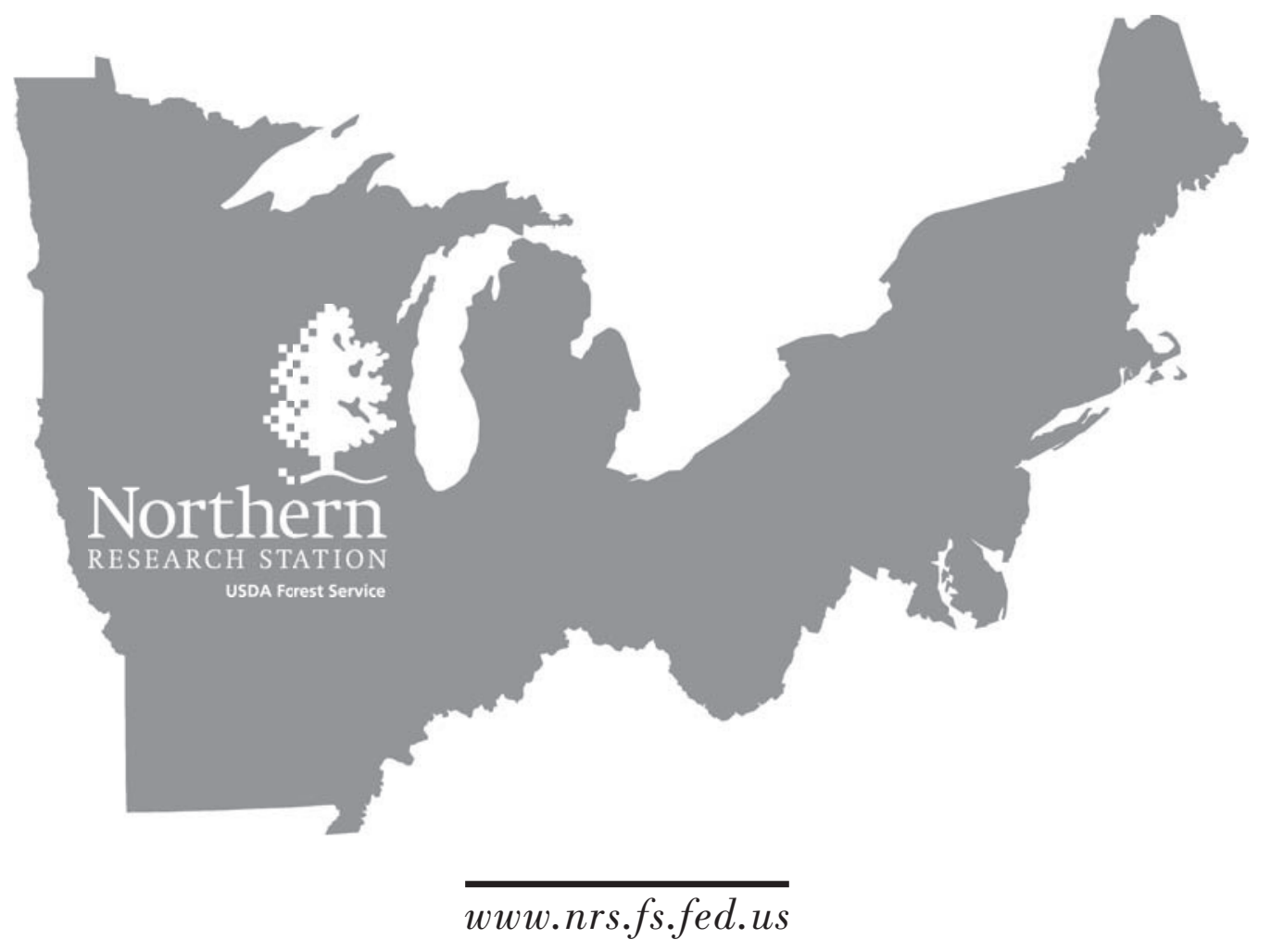

